\title{
Structural, FTIR, Optical and Dielectric Properties of Zn1-xAlxO Ceramics For Advanced Applications
}

Ahmed Sedky ( $\sim$ sedky196000@hotmail.com )

Assiut University

Atif Mossad Ali

King Khalid University

H. Algarni

King Khalid University

\section{Research Article}

Keywords: Residual stress, Elastic constants, Energy Gap, Ac Conductivity and F-Factor

Posted Date: January 11th, 2022

DOI: https://doi.org/10.21203/rs.3.rs-1211609/v1

License: (1) This work is licensed under a Creative Commons Attribution 4.0 International License.

Read Full License 


\title{
Structural, FTIR, Optical and Dielectric Properties of $\mathrm{Zn}_{1-\mathrm{x}} \mathrm{Al}_{\mathrm{x}} \mathrm{O}$ Ceramics For Advanced Applications
}

\author{
A. Sedky ${ }^{a^{*}}$, Atif Mossad Ali ${ }^{\mathrm{b}}$ and H.Algarni ${ }^{\mathrm{b}}$ \\ (a) Department of Physics, Faculty of Science, Assiut University, Assiut 71516, Egypt \\ (b) Physics Department, Faculty of Science, King Khalid University, Abha, Saudi Arabia
}

\begin{abstract}
We report here the structural, FTIR, optical and dielectric properties of $\mathrm{Zn}_{1-\mathrm{x}} \mathrm{Al}_{\mathrm{x}} \mathrm{O}$ with $\mathrm{x}=$ $00.00<\mathrm{x} \leq 0.20)$ ). The wurtzite structure is conformed to all samples and the lattice constants, crystallite diameter, porosity and average crystalline size are generally decreased. The residual stress is compressive for pure samples, but it is changed to tensile for the doped samples. Interestingly, Debye temperature and elastic modulus are increased as $\mathrm{x}$ increases to 0.10 , followed by a decrease at $x=0.20$. Two different energy gaps $E_{g h}$ and $E_{g l}$ are apparent for each sample, corresponding of two transition absorption peaks. Interestingly, the $\Delta \mathrm{E}=\left(\mathrm{E}_{\mathrm{gh}}-\mathrm{E}_{\mathrm{gl}}\right) \sim$ 0.60 for all samples. Further, the residual dielectric constant is decreased by increasing $\mathrm{x}$ to 0.10 , followed by a sharp increase at $\mathrm{x}=0.20$ while the opposite behavior for $\left(\mathrm{N} / \mathrm{m}^{*}\right)$. The dielectric constant $\varepsilon^{\prime}$ is slightly increased as $\mathrm{x}$ increases to 0.025 , followed by a sharp increase as $\mathrm{x}$ increases to 0.20 , as well as the ac conductivity $\sigma^{\prime}$. The conduction is electronic for $\mathrm{x} \leq 0.025$ samples, but it is changed to hole with an increase of $x$ to 0.20 . The binding energy $W_{m}$ was decreased as $\mathrm{x}$ increases to 0.20 , but there is no exact trend against $\mathrm{x}$ for the behaviors of minimum hopping distance $\mathrm{R}_{\min }$ and density of localized states $\mathrm{N}$. In addition, the density of states at Fermi level $\mathrm{N}\left(\mathrm{E}_{\mathrm{F}}\right)$ has an optimum value at $195 \mathrm{KHz}$ for all samples. The F-factor for solar cell design is increased as $\mathrm{x}$ increases to 0.10 , but it is almost constant at $\mathrm{x}=0.20$. The Cole-Cole plot is a straight line for $\mathrm{x}=0.00$, a semicircle arc for $\mathrm{x}=0.025$ and a complete semicircle for $x \geq 0.05$. The impedance resistance of grain $Z^{\prime}(g)$ and grain boundaries $Z^{\prime}(g b)$ are gradually decreased by increasing $\mathrm{x}$ to 0.20 . These outcomes indicate that the addition of $\mathrm{Al}$ to $\mathrm{ZnO}$ shifts the mechanical, optical, and dielectric medium to higher values, which is strongly recommended for the design of optoelectronic and solar cell instruments.
\end{abstract}

Keywords: Residual stress; Elastic constants; Energy Gap; Ac Conductivity and F-Factor Corresponding author*: sedky196000@hotmail.com; asdky@science.au.edu.eg 


\section{1- Introduction}

Wurtzite structure of pure n-type $\mathrm{ZnO}$ with $3.2 \mathrm{eV}$ and 60 Urbach energy has been used in optoelectronic and solar cell devices [1-4]. The sintering of $\mathrm{ZnO}$ and also doping by 3-d elements (TM) exhibits intrinsic defects due to oxygen vacancies and in turn introduces donor states below $\mathrm{CB}$ of $\mathrm{ZnO}$ to be convenient for such devices [5-13].

The vibration of the lattice in solids in general and in $\mathrm{ZnO}$ compounds in particular has been considered early as the subject of many applications, such as optical Kerr shutters (OKS), switching devices, and detectors. Many experimental techniques have been utilised to assess the suitability of $\mathrm{ZnO}$-based compound materials for such applications.

Among those, FTIR analysis significantly helps in approximating the relationship between the spin vacancy and the carrier concentration. Furthermore, it gives an ascertainable indicator of the purity and nature of the metal oxides in the compound. The absorption bands of $\mathrm{ZnO}$ arising from interatomic vibrations, stretching and deformation of $\mathrm{O}-\mathrm{H}$ are assigned to water adsorption on the $\mathrm{Zn}$ surface, and some other bands [14-17].

The mechanism of the $\mathrm{ZnO}$ conduction band (CB) usually arises when the $4 \mathrm{~s}$ orbital of $\mathrm{Zn}$ is wide enough to allow for effective charge transfer [18-20]. Consequently, the electrons are excited from the valence state due to the absorption of light, and consequently the electron-hole pairs are generated. Above the limit of the $\mathrm{ZnO}$ band gap, the recorded signals of photon energy are due to non-radiative and Urbach tail processes. Furthermore, the energy of photons for creating electron-hole pairs can be considered only for materials with a larger Urbach energy like $\mathrm{ZnO}[\mathbf{2 1}]$.

The electronic traps of $\mathrm{ZnO}$ are mainly localized at the grain boundaries and usually adsorbed oxygen and capture some donor state electrons [22]. Consequently, the Schottky barrier capacitance is found to be frequency dependent due to the finite time constants $\tau(\tau=(1 / \omega)=$ RC) of the deep trap states generated in the depletion layer [23-24]. Ac impedance spectroscopy is able to separate the electric response in different regions of $\mathrm{ZnO}$ within the range of $\tau$ [25-26]. This response is entirely characterized by the complex dielectric parameters against ac field frequency response [27-29].

Materials with high dielectric constants such as $\mathrm{ZnO}$ have received special attention due to the rapid developments in telecommunications and multilayer capacitors are required for microwave integrated circuits [30-32]. In contrast, materials that have a low dielectric constant are potential candidates for nonlinear optical and high-frequency devices, which are necessary for such applications [33]. However, some parameters have a great influence on improving $\mathrm{ZnO}$ dielectric constants, such as valence state, content, magnetic moment of TM, and also intrinsic defects [3438].

The dielectric properties of $\mathrm{ZnO}$ can be tuned by introducing dopants into the $\mathrm{ZnO}$ host matrix with 3-d transition-elements [39-47]. For example, the dielectric constants and ac conductivity of $\mathrm{Fe}, \mathrm{Ni}, \mathrm{Co}$, and $\mathrm{Mn}$ doped into $\mathrm{ZnO}$ are significantly decreased. But, ac conductivity increases with an increase in frequency, and complex impedance analysis shows single circular arc type behavior, suggesting the dominance of grain resistance [48-50]. The density of localized states at the Fermi level $\mathrm{N}\left(\mathrm{E}_{\mathrm{F}}\right)$ and the binding energy $\mathrm{W}_{\mathrm{m}}$ decrease as the doping content increases. This behavior has been explained in terms of the frequency dependence of the s, p-d exchange interaction between the $\mathrm{Zn}$ and dopants in terms of Maxwell-Wagner type interfacial polarization and Koops's phenomenological theory [51-53].

The electrical properties of $\mathrm{Al}$ doped with $\mathrm{ZnO}$ are presented by Sedky et.al [54-55]. It is found the addition of $\mathrm{Al}$ generally decreases the nonlinear behavior of $\mathrm{ZnO}$ and, therefore, the dc electrical conductivity has increased. It is believed that the excess electron density and structural distortion, produced by $\mathrm{Al}$ doping in both under and over doped regions, are responsible for the above behavior. With this purpose in mind, structural, FTIR analysis, optical and dielectric behaviors will be examined on the same batch of samples. Interestingly, some important physical 
parameters are well estimated, such as Debye temperatures, elastic constants, energy gap, dielectric loss, $\mathrm{N} / \mathrm{m}^{*}$, inter-atomic distance $\mathrm{R}$, density of states at Fermi level $\mathrm{N}\left(\mathrm{E}_{\mathrm{f}}\right), \mathrm{F}$-factor, and ac impedance for solar cell applications. This study may have recommended these samples for optoelectronic and solar cell investigation.

\section{2- Experimental Details}

$\mathrm{Zn}_{1-\mathrm{x}} \mathrm{Al}_{\mathrm{x}} \mathrm{O}$ samples with $\mathrm{x}=0.00,0.05 .0 .10,0.20$ were synthesized by using a conventional solid-state reaction method. The powders of $\mathrm{ZnO}$ and $\mathrm{Al} 2 \mathrm{O} 3$ (Aldrich 99.999 purity) are thoroughly mixed in the required proportions and calcined at $900{ }^{\circ} \mathrm{C}$ in air for a period of 16 hours. The resulting powders are ground, mixed, and pressed into disks of $1 \mathrm{~cm}$ diameter and 0.3 $\mathrm{cm}$ thick. The pellets are then separately sintered at temperatures of $1200^{\circ} \mathrm{C}$ for 12 hours in the air and then suddenly cooled (quenched) in air to room temperature. The bulk density of the samples is measured in terms of their weight and volume. The phase purity of the samples was

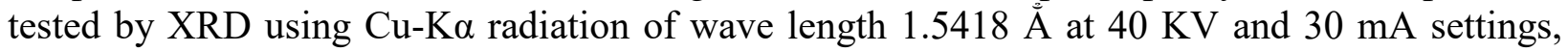
and $\left(20^{\circ}-70^{\circ}\right)$ diffraction angles with a step of $0.06^{\circ}$. FTIR absorption spectra of the samples were carried out in the range of $\left(400-4000 \mathrm{~cm}^{-1}\right)$, with $4 \mathrm{~cm}^{-1}$ resolution and $2(\mathrm{~cm} / \mathrm{s})$ scanning speed using a spectrum 400-FT-1R/FT-NIR spectrometer. The samples were homogenized in a spectroscopic grade of $\mathrm{KBr}$ carrier in an agate mortar and pressed into $2 \mathrm{~mm}$ pellets. The grinding time was minimized as possible to avoid structure deformation, ion exchange and water absorption from the atmosphere. The optical properties at room temperature were measured against wavelength (200-1000 nm) using a JascoV-570 (Japan) computer programmable double beam with UV-visible-NIR spectrophotometer at standard incidence with a scan speed of 1000 $\mathrm{mm}$ min -1 . photometric accuracy of $( \pm 0.002-0.004)$ absorbance and $\pm 0.3 \%$ transmittance is motioned. The dielectric properties are measured by broadband dielectric spectroscopy (BDS) utilizing a high resolution Alpha analyzer with an active sample head (Novo control GmbH). The complex dielectric measurements were obtained at room temperature using a precision impedance analyzer model $4295 \mathrm{~A}$ in the frequency range of 1 to $10^{7} \mathrm{~Hz}$. The amplitude of the AC electric signal applied to the samples is about $1 \mathrm{~V}$. The surface of the pellets is well polished to dryness and metalized with a thin layer of silver paste in order to obtain two parallel plates. The pellets are sandwiched between two gold-plated stainless steel electrodes of $20 \mathrm{~mm}$ in diameter in parallel plate geometry. Fused silica fibers with a diameter of $50 \mathrm{~mm}$ are used as spacer material. The ac conductivity and modulus of complex impedance $Z$ as a function of frequency are well recorded. From the impedance spectra, values of the real $Z$ ' and the imaginary $Z^{\prime \prime}$ parts of the complex impedance could be obtained.

\section{3- Results and Discussion}

\section{1- Structural Analysis}

It is evident from the XRD patterns shown in Figure 1 (a) that all samples show a wurtzite structure ICSD 01-079-0208 (space group P63mc) of ZnO. No additional lines could be formed for the samples of $\mathrm{x}=0.00$ and 0.025 samples, but as $\mathrm{x}$ is increased to and above 0.025 , some unidentified lower peaks could be seen at $2 \theta=30.96^{\circ}$ for $\mathrm{x}=0.05 ; 2 \theta=30.96^{\circ}, 55.5^{\circ}, 60^{\circ}$ for $\mathrm{x}=$ 0.10 ; and $2 \theta=30.96^{\circ}, 48.74^{\circ}, 55.5^{\circ}, 60^{\circ}$ for $\mathrm{x}=0.20$. This is because the bond energy of $\mathrm{Al}_{2} \mathrm{O}_{3}$ is higher than $\mathrm{ZnO}$, and therefore more energy is required for $\mathrm{Al}$ ions to enter the $\mathrm{ZnO}$ lattice to form the Al-O bond and therefore some of secondary phase could be formed [56-59]. The lattice parameters $a$ and $c$, listed in Table 1, are gradually decreased by increasing x. The c/a, Uparameter and $\mathrm{ZnO}$ bond length $\mathrm{L}$ are almost the same as reported for $\mathrm{ZnO}$ [60-65]. This is due to the smaller ionic size of $\mathrm{Al}^{3+}(0.51 \AA)$ than that of $\mathrm{Zn}^{2+}(0.74 \AA$ ) $)$ at the same tetrahedral foldcoordination [66-70]. The porosity calculated by; $P S=\left[1-\left(\rho_{\text {exp }} / \rho_{\text {th }}\right)\right]$ is slightly decreased as $\mathrm{x}$ increases to 0.10 , followed by an increase at $\mathrm{x}=0.20$. This behavior indicated that $\mathrm{Al}$ up to 0.10 helps as possible for decreasing the number of pores of $\mathrm{ZnO}$. 


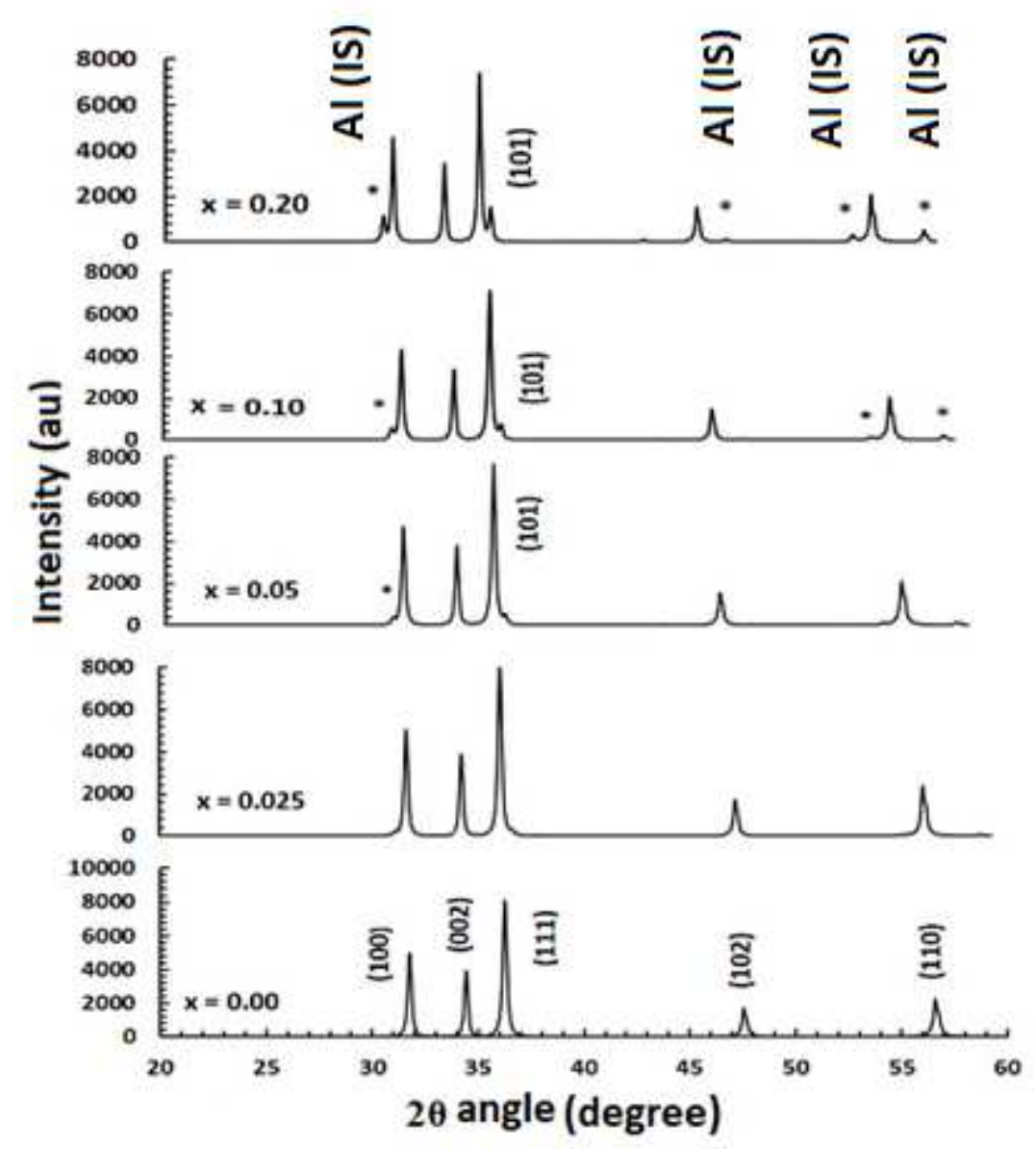

Figure 1(a): XRD patterns for pure and $\mathrm{Al}$ doped samples

The crystallite size $D_{\text {hkl }}$ given by $D_{h k l}=\frac{K \lambda}{\beta \cos \theta}$ [71] for the most intense peaks listed in Table 1 are decreased by $\mathrm{x}$ to 0.20 . The vice is versa for dislocation density $\delta$ calculated by $\left(1 / \mathrm{D}_{\mathrm{hkl}}{ }^{2}\right)$. The micro-lattice strain $\varepsilon_{m s}=\frac{\beta \cos \theta}{4}$ listed in Table 1 is positive and increased by Al. While lattice strain $\varepsilon_{\mathrm{ls}}=\left(\mathrm{c}-\mathrm{c}_{\mathrm{o}}\right) / \mathrm{c}_{\mathrm{o}}$ is positive for pure $\mathrm{ZnO}$, but it changes to negative for the doped samples. Regardless of its sign, this behavior indicates that $\mathrm{Al}$ helps as a possible $\mathrm{ZnO}$ for few lattice defects or distortions. [72-74]. The SEM micrographs shown in Figure 1(b) indicates that nearly, no second phases are formed at grain boundaries, but the grains are randomly distributed over the matrix structure. As listed in Table $1, \mathrm{Al}$ content up to $\mathrm{x} \leq 0.10$ decreased the average grain size of ZnO DSEM, followed by an increase at $\mathrm{x}=0.20$ as obtained from XRD analysis.

Table 1: $\mathrm{I}_{\mathrm{avg}}, \mathrm{a}, \mathrm{c}, \mathrm{c} / \mathrm{a}, \mathrm{V}, \mathrm{U}, \mathrm{L}, \boldsymbol{\delta}, \rho, P_{\mathrm{s}}, \varepsilon_{\mathrm{ms}}, \varepsilon_{\mathrm{ls}}, \sigma$ and $\mathrm{n}$ for the samples

\begin{tabular}{|c|c|c|c|c|c|c|c|}
\hline $\mathbf{x}$ & $\begin{array}{c}\mathbf{a} \\
(\stackrel{\tilde{A}}{)})\end{array}$ & $\begin{array}{c}\mathbf{c} \\
(\stackrel{\breve{A}}{)})\end{array}$ & $\mathbf{c} / \mathbf{a}$ & $\begin{array}{c}\mathbf{V} \\
(\mathbf{A})^{3}\end{array}$ & $\begin{aligned} & \varepsilon_{\text {ls }} \\
& \times 10^{-3}\end{aligned}$ & $\mathbf{U}$ & $\begin{array}{c}\mathbf{L} \\
(\mathbf{A})\end{array}$ \\
\hline 0.00 & 3.252 & 5.208 & 1.601 & 47.697 & 0.27 & 0.379 & 1.991 \\
\hline
\end{tabular}




\begin{tabular}{|c|c|c|c|c|c|c|c|}
\hline 0.025 & 3.247 & 5.201 & 1.602 & 47.486 & -1.08 & 0.380 & 1.987 \\
\hline 0.05 & 3.242 & 5.196 & 1.603 & 47.295 & -2.04 & 0.380 & 1.987 \\
\hline 0.10 & 3.231 & 5.188 & 1.606 & 46.902 & -3.57 & 0.380 & 1.990 \\
\hline 0.20 & 3.237 & 5.191 & 1.604 & 46.665 & -4.92 & 0.380 & 1.981 \\
\hline $\mathbf{X}$ & $\begin{array}{c}\boldsymbol{\rho} \text { th } \\
\left(\mathbf{g} / \mathbf{c m}^{\mathbf{3}}\right)\end{array}$ & $\begin{array}{c}\boldsymbol{\rho} \mathbf{\text { exp }} \\
\left(\mathbf{g} / \mathbf{c m}^{\mathbf{3}}\right)\end{array}$ & $\boldsymbol{P} \mathbf{s}$ & $\mathbf{D} \mathbf{( n m )})$ & $\begin{array}{c}\mathbf{\delta} \times \mathbf{1 0}^{-4} \\
(\mathbf{n m})^{-2}\end{array}$ & $\begin{array}{c}\mathbf{E m s} \\
\times \mathbf{1 0}^{-3}\end{array}$ & $\begin{array}{c}\mathbf{D} \text { SEM } \\
(\boldsymbol{\mu m})\end{array}$ \\
\hline 0.00 & 5.794 & 5.451 & 0.059 & 41.830 & 5.72 & 3.32 & 2.060 \\
\hline 0.025 & 5.630 & 5.312 & 0.056 & 41.167 & 5.90 & 3.376 & 1.790 \\
\hline 0.05 & 5.529 & 5.244 & 0.051 & 38.983 & 6.58 & 3.566 & 1.610 \\
\hline 0.10 & 5.253 & 5.053 & 0.038 & 37.230 & 7.21 & 3.734 & 1.780 \\
\hline 0.20 & 5.061 & 4.710 & 0.069 & 39.637 & 6.37 & 3.507 & 2.230 \\
\hline
\end{tabular}
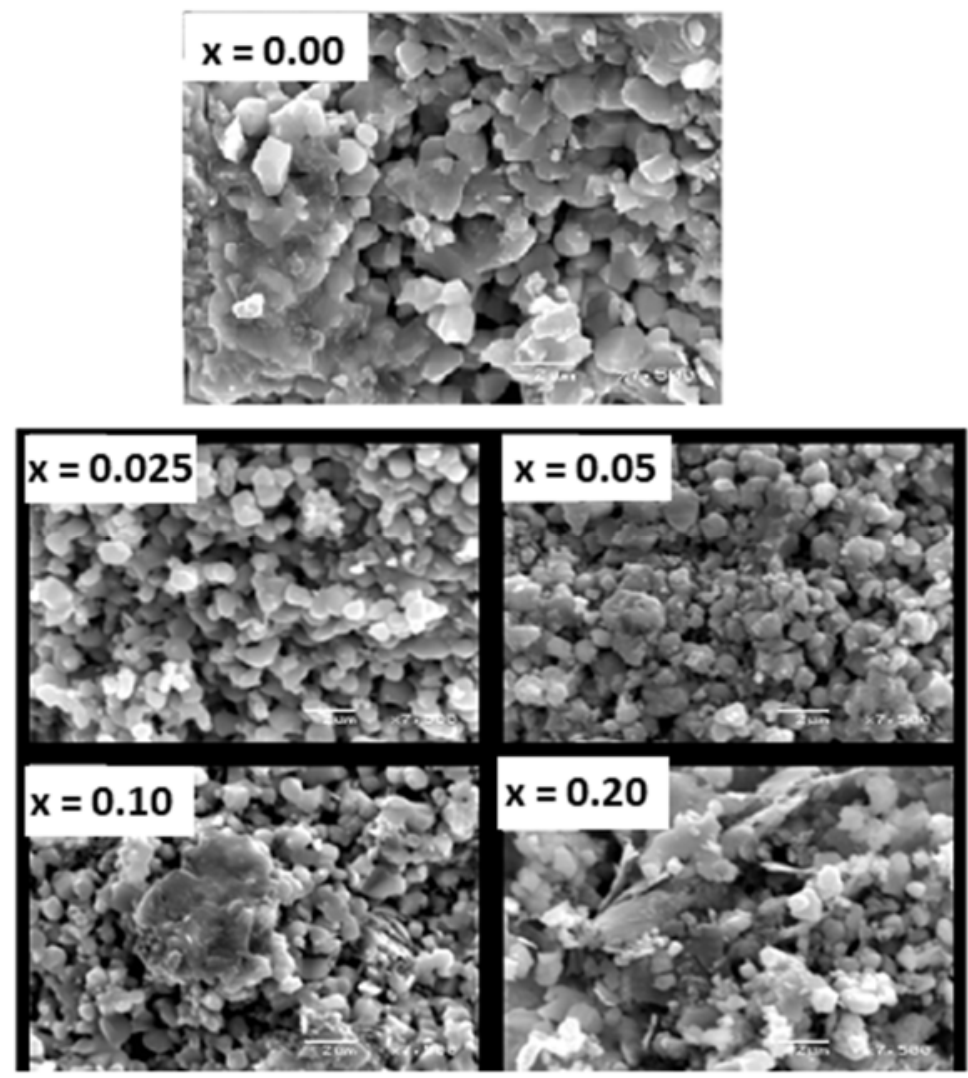

Figure 1(b): SEM micrographs for pure and Al doped samples

\section{2- FTIR Analysis}

Figure 2 (a) shows FTIR spectra against wave number $\bar{v}$ for the samples and also the values of wave numbers $\bar{v}$ against absorption peaks are listed in Table 2 . Firstly, there is a clear peak recorded at $3423.36,3442.14,3417.14,3417.34,3442.18 \mathrm{~cm}^{-1}$, respectively, which is related to $\mathrm{O}-\mathrm{H}$ stretching vibrations for $\mathrm{ZnO}$ [75-76]. One peak is only recorded at $2924.21 \mathrm{~cm}^{-1}$ for the $\mathrm{x}=$ 0.20 sample, but it disappeared for the other samples, even for $\mathrm{ZnO}$, which may be related to the solubility limit discussed above. Interestingly, the functional peak observed at $1630 \mathrm{~cm}^{-1}$ due to $\mathrm{H}-\mathrm{O}-\mathrm{H}$ bonding vibrations and $\mathrm{C}=\mathrm{C}$ stretching, is absent for all samples [77-78]. Some other peaks were only obtained at $1426.07 \mathrm{~cm}^{-1}$ and $1436.68 \mathrm{~cm}^{-1}$ for $\mathrm{x}=0.00$ and 0.20 . In contrast, there are also identified peaks recorded at $673.56,672.18,671.84,668.13$ for $\mathrm{x}=0.00,0.025$, 0.05 and 0.10 , but it is absent for $\mathrm{x}=0.20$. However, the presence of the peak is an evidence for 
incorporation of $\mathrm{Al}^{3+}$ ions into the $\mathrm{ZnO}$ matrix and corresponds to the $\mathrm{C}=\mathrm{C}, \mathrm{C}=\mathrm{O}, \mathrm{C}-\mathrm{N}$ and $\mathrm{O}-\mathrm{H}$ stretching and $\mathrm{C}-\mathrm{H}$ bending vibration [79-80]. Among the absorption peaks observed between (451.97-556.32 $\mathrm{cm}^{-1}$ ) which corresponds to the active modes of $\mathrm{ZnO}$ related to hexagonal structure [81-82]. This means that the $\mathrm{ZnO}$ structure is slightly different than the ideal case for $\mathrm{x}$ $=0.20$, as obtained from XRD analysis. This behavior indicates that Al shifted the bending and stretching vibrations of $\mathrm{ZnO}$ to lower $\bar{v}$. This is attributed to formation of $\mathrm{ZnAl}_{2} \mathrm{O}_{4}$ bond of more length chain and really that the $\mathrm{Al}$ had intense $\mathrm{ZnO}$ and moderate metal oxide modes in the $\mathrm{ZnO}$ matrix structure [83-84].

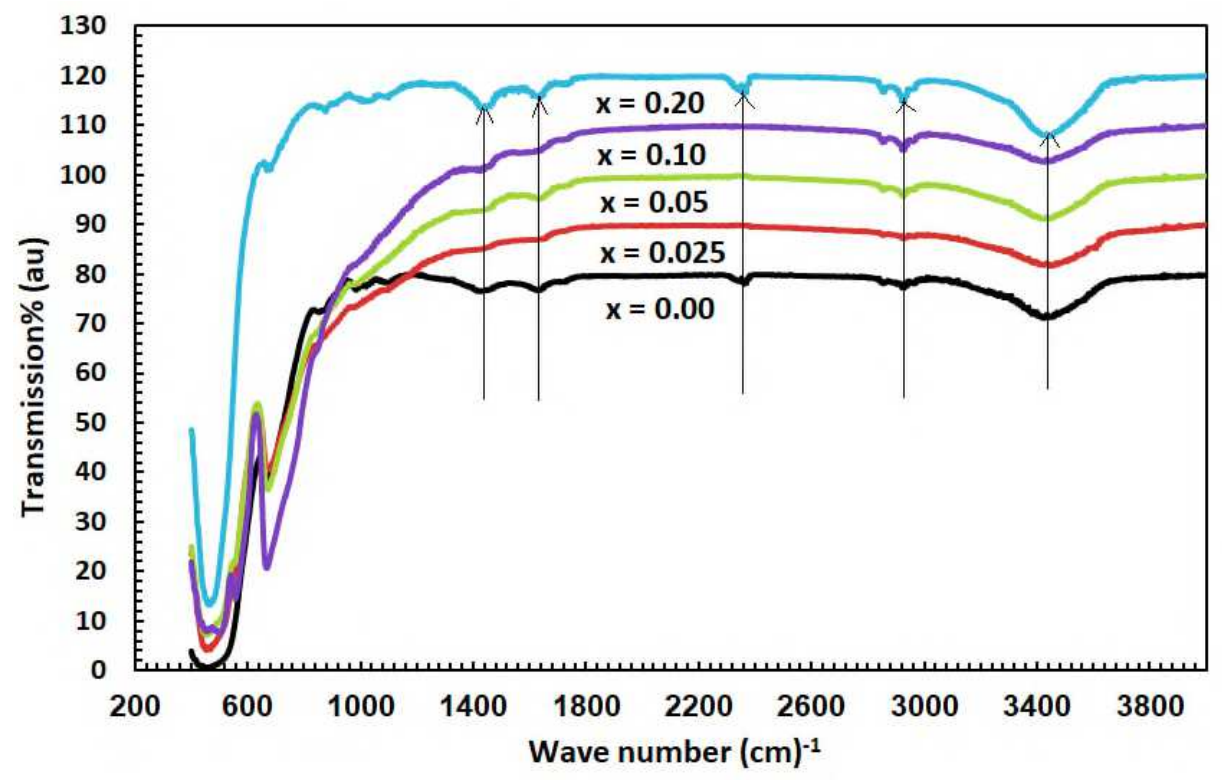

Figure 2 (a): FTIR spectra of for pure and Al doped samples

Table 2: FTIR absorption peaks, residual stress, Poisson's ratio , and elastic constants for the samples

\begin{tabular}{|c|c|c|c|c|}
\hline $\begin{array}{l}x=0.00 \\
v(\mathrm{~cm})^{-1}\end{array}$ & $\begin{array}{c}x=0.025 \\
v(\mathrm{~cm})^{-1}\end{array}$ & $\begin{array}{l}x=0.05 \\
v(\mathrm{~cm})^{-1}\end{array}$ & $\begin{array}{l}x=0.10 \\
v(\mathrm{~cm})^{-1}\end{array}$ & $\begin{array}{l}x=0.20 \\
v(\mathrm{~cm})^{-1}\end{array}$ \\
\hline 3423.36 & 3442.14 & 3417.14 & $\begin{array}{ll}34 & 7.34\end{array}$ & 3442.18 \\
\hline 2330 & ב------ & --------- & -------- & 2340.21 \\
\hline 1590 & -------- & 1610 & -------- & 1623 \\
\hline 1426.07 & $\begin{array}{l}-------- \\
\end{array}$ & --------- & 1428.8 & 1436.68 \\
\hline 673.56 & 672.18 & 671.84 & 668.13 & ---------- \\
\hline --------- & --------- & --------- & 556.32 & --------- \\
\hline --------- & --------- & --------- & 502.43 & --------- \\
\hline \multirow[t]{2}{*}{452.31} & 452.11 & 451.97 & --------- & 467.76 \\
\hline & & $\gamma$ & & \\
\hline \multirow[t]{2}{*}{0.304} & 0.305 & 0.307 & 0.311 & 0.301 \\
\hline & & $\sigma(\mathbf{G p a})$ & & \\
\hline \multirow[t]{2}{*}{-0.063} & 0.250 & 0.474 & 0.832 & 1.145 \\
\hline & & $\mathrm{S}_{11}\left(\mathrm{D} / \mathrm{cm}^{2}\right)$ & & \\
\hline \multirow[t]{2}{*}{$2.23 \mathrm{E}+11$} & $2.23 \mathrm{E}+11$ & $2.23 \mathrm{E}+11$ & $2.76 \mathrm{E}+11$ & $2.39 \mathrm{E}+11$ \\
\hline & & $\mathrm{S}_{12}\left(\mathrm{D} / \mathrm{cm}^{2}\right)$ & & \\
\hline $9.73 \mathrm{E}+10$ & $9.78 \mathrm{E}+10$ & $9.86 \mathrm{E}+10$ & $1.25 \mathrm{E}+11$ & $1.03 \mathrm{E}+11$ \\
\hline
\end{tabular}


Debye temperature $\theta_{\mathrm{D}}$ at about $500 \mathrm{~cm}^{-1}$ is given by [85-87];

$$
\theta_{D}(K)=\frac{h c \overline{\Delta v}}{K_{B}}=1.439 \overline{\Delta v}
$$

Figure 2 (b) shows that $\theta_{\mathrm{D}}$ suddenly increases as $\mathrm{x}$ increases to 0.10 , followed by a sudden decrease at $x=0.20$. However, this behavior is attributed to the shift in the wave number of FTIR bands to higher/lower values against x content as listed in Table 2.

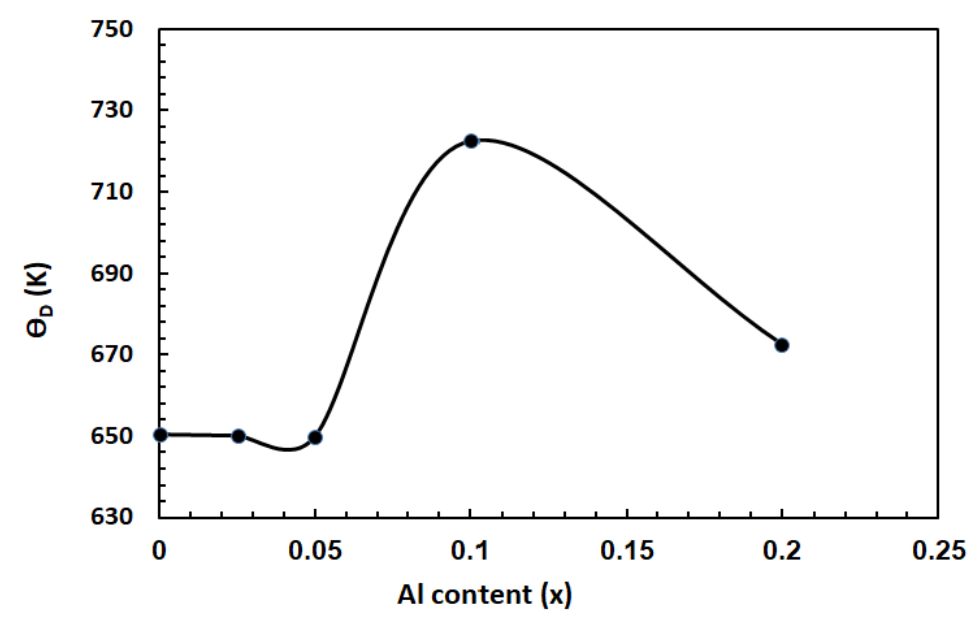

Figure $2(b)$ : Debye temperature $\left(\theta_{D}\right)$ versus $\mathrm{Al}$ content for the samples

The strength of the interaction between $\mathrm{Zn}$ cat-ions and $\left(\mathrm{O}^{-2}\right)$ ions of $\mathrm{ZnO}$, the force constant $\mathrm{K}_{\mathrm{t}}$ can be calculated using; $K_{t}=0.076 \mathrm{~W} \Delta v^{2}[\mathbf{8 8 - 8 9}]$. Also, the stiffness constants $\mathrm{S}_{11}$ and $\mathrm{S}_{12}$ are easily calculated in terms of Poisson's ratio $\gamma$ as; $S_{11}=\left(K_{t} / c\right), S_{12}=\left(S_{11} \gamma / 1-\gamma\right)$ and $\gamma=0.324$ (11.043PS) [90]. It is evident from Table 2 that $(\gamma>0.26)$ for all samples which indicates ductile nature [91]. The residual stress $\sigma$ is calculated by [92-93];

$$
\sigma=\frac{\left[2 S_{13}^{2}-S_{33}\left(S_{11}+S_{12}\right)\right] \varepsilon_{L s}}{2 S_{13}}=-232.8 \varepsilon_{L s}
$$

Where $\mathrm{S}_{13}, \mathrm{~S}_{33}, \mathrm{~S}_{11} \mathrm{~S}_{12}$ are respectively equal 104.2, 213.8, 208.8 and 119.7 GPa for ZnO [9495]. As listed in Table $2, \sigma$ is negative (compressive-like behavior) for $\mathrm{ZnO}$. In contrast, it is positive (tensile-like behavior) for the doped samples, indicating that $\mathrm{Al}$ was able to eliminate the compressive stress of $\mathrm{ZnO}$ and turn it into tensile stress. This may be related to the number of pores and the lattice defects discussed above [96-97]. Young $Y$, bulk modulus $\beta$ and rigidity modulus $\mathrm{G}$ are determined by [98-103];

$$
Y=\frac{\left(S_{11}-S_{22}\left(S_{11}+2 S_{12}\right)\right.}{\left(S_{11}+S_{12}\right)} ; \beta=\frac{S_{11}+2 S_{12}}{3} ; G=\frac{Y}{2(\gamma+1)} \text { (3) }
$$

As shown in Figure 3, both of them are increased as $\mathrm{x}$ increased to 0.10, followed by a decrease at $\mathrm{x}=0.20$. This increase may be related to the shrinkage of inter-atomic bond length $L$ which subsequently controls the $\mathrm{ZnO}$ bond strength [104-105]. 


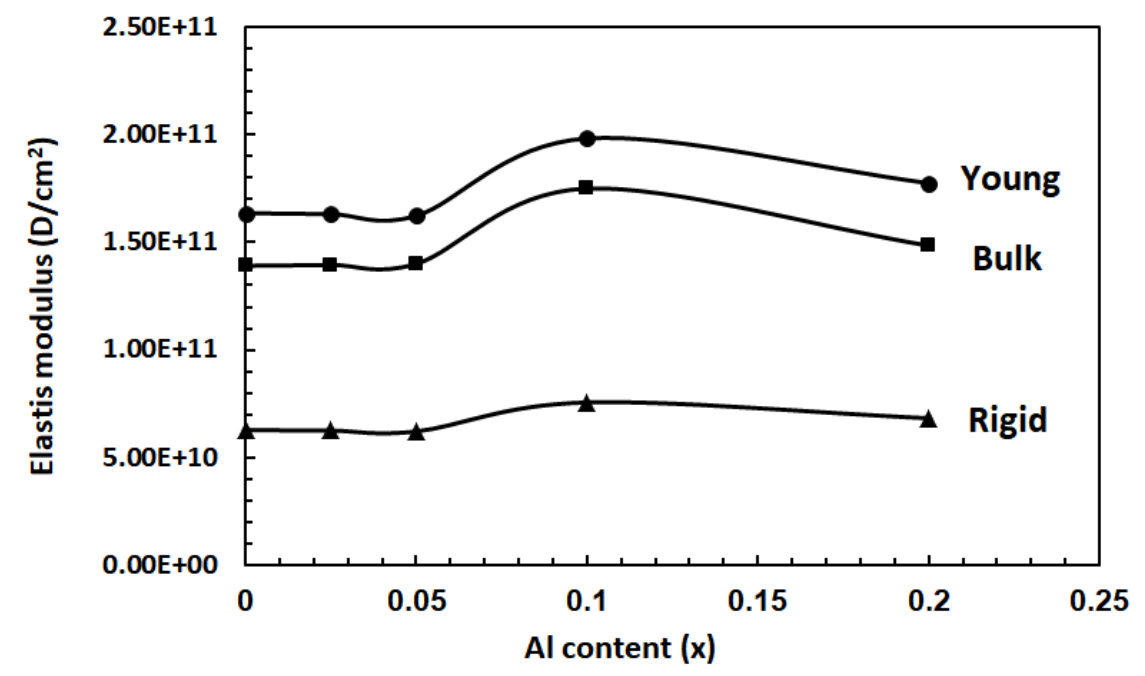

Figure 3: Elastic modulus (Y,B,G) versus $\mathrm{Al}$ content for the samples

\section{3-Optical Measurements}

Reflectance (R/A) versus wave lengths, as shown in Figure 4(a-b), reveals two minimum/maximum regions for all samples at about $400 \mathrm{~nm}$, which may be related to increasing free carrier density in the near-UV region [106]. Interestingly, the change in (R/A) for Al-doped samples is related to the oxygen vacancies, which usually make $\mathrm{ZnO}$ suitable for gas sensors [107-108]. As given in Table 3 , the first $A_{\max }$ or $R_{\min }$ occurs at $(\lambda(1) \max =314 \mathrm{~nm})$ for all samples, while the second $A_{\max }$ or $R_{\min }$ occurs at $\lambda(2) \max =352,364,350,344$ and $346 \mathrm{~nm}$, respectively. Therefore, first exciton energies $\mathrm{E}_{\mathrm{ex}}(1)$ is $3.953 \mathrm{eV}$ for all samples, while the second $\mathrm{E}_{\mathrm{ex}}(2)$ is decreased for $\mathrm{x}=0.025$, followed by an increase to $\mathrm{x}=0.20$. This means that the required energy for creating electron-hole pairs is decreased by 0.025 of $\mathrm{Al}$, followed by an increase of up to 0.20 .

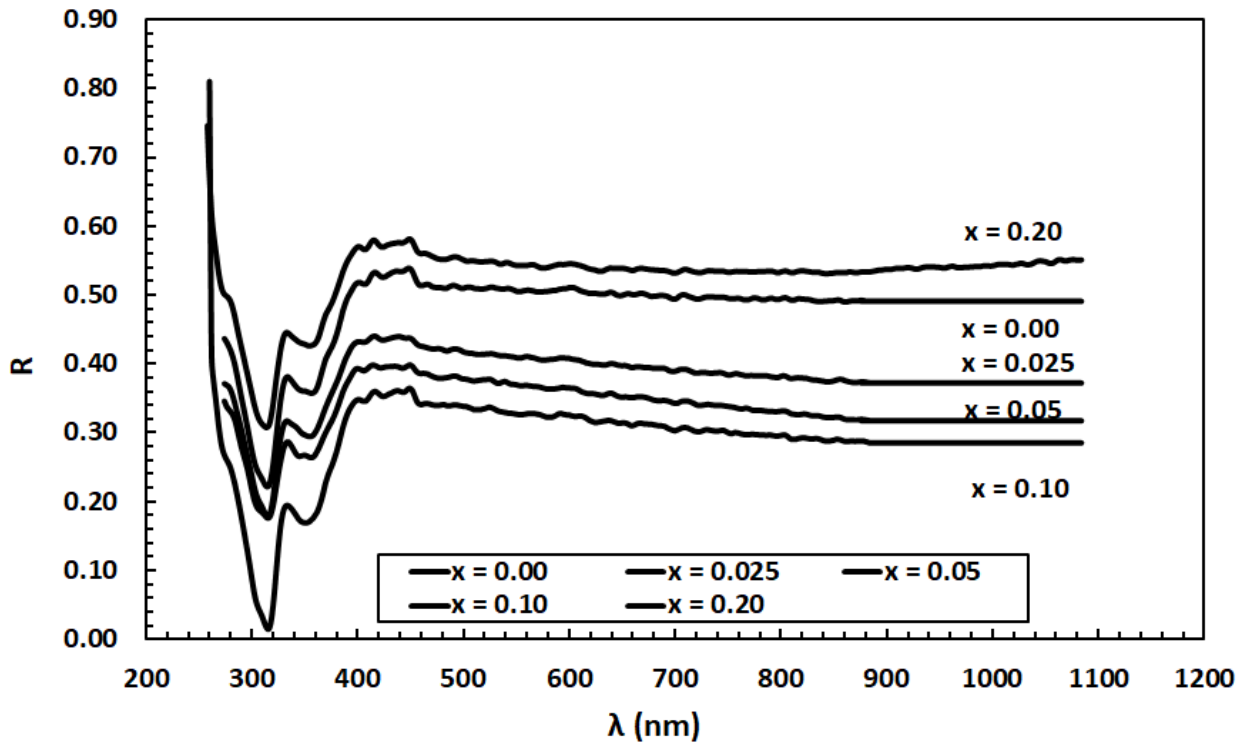

Figure 4 (a): Reflectance (R) versus wave length for pure and Al doped samples 


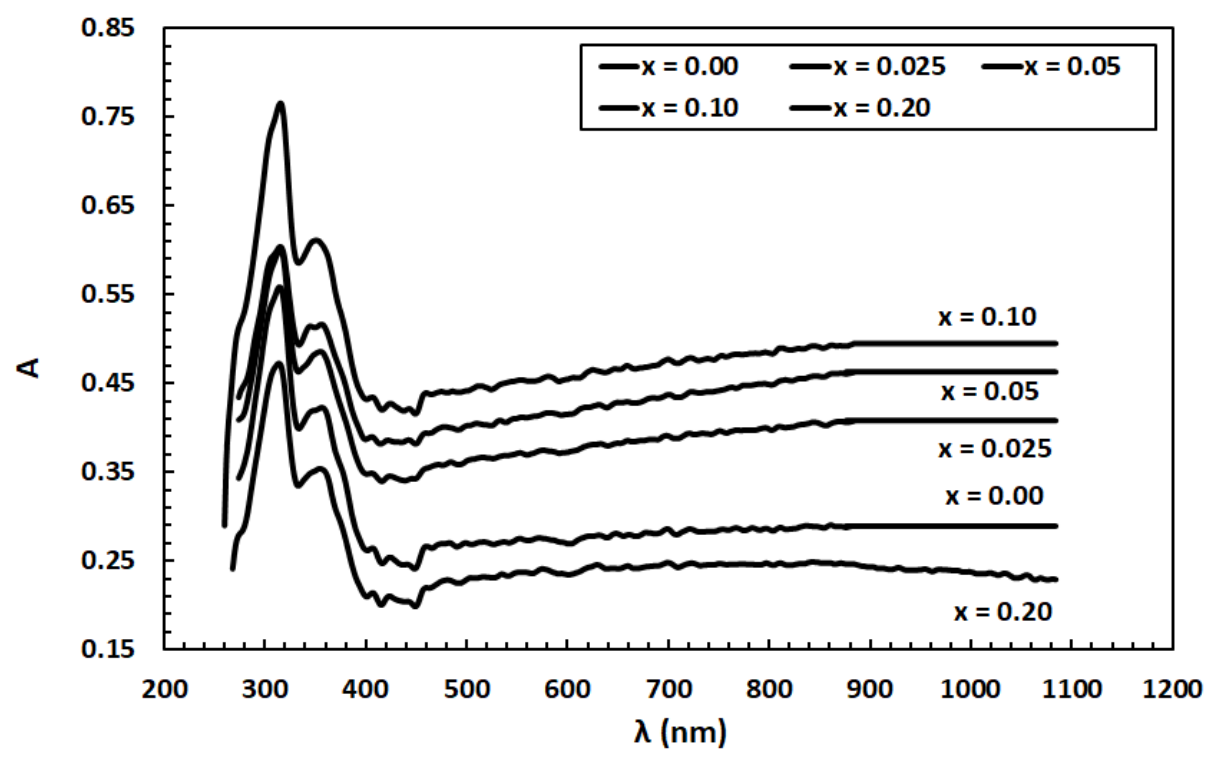

Figure 4 (b): Absorption (A) versus wave length for pure and Al doped samples

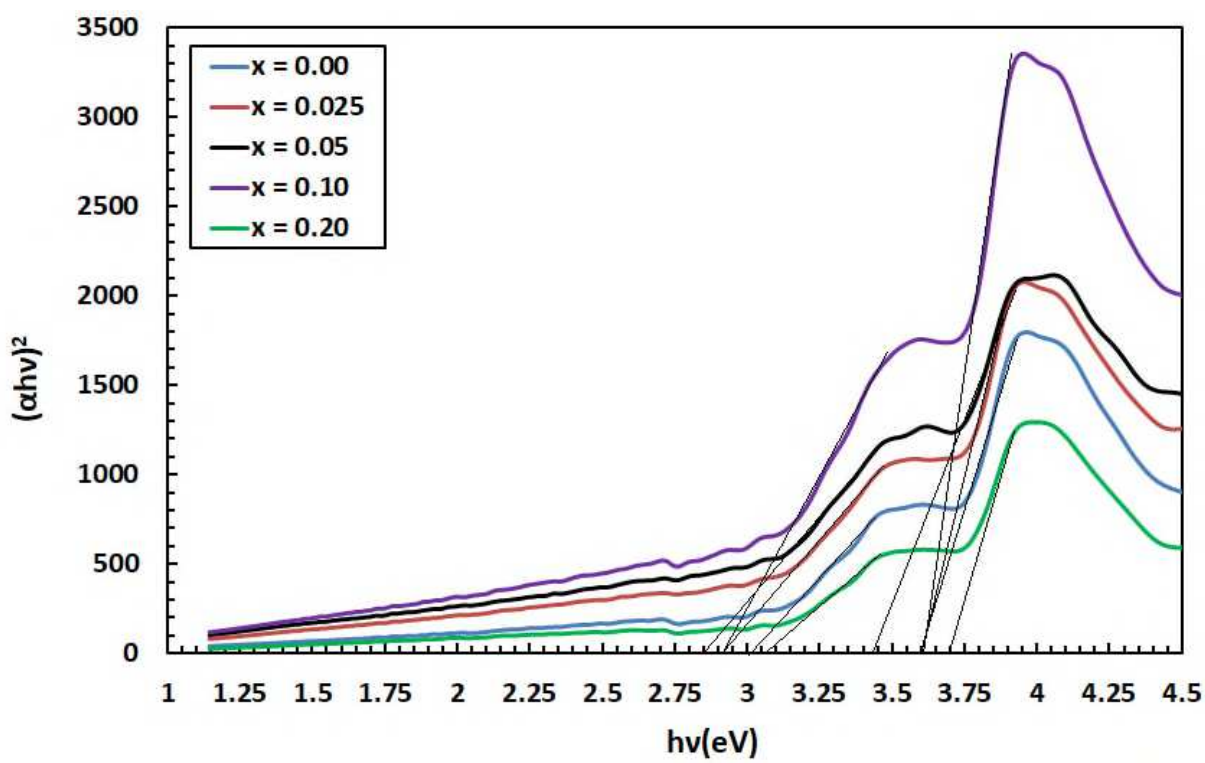

Figure 5: $(\alpha h v)^{2}$ versus photon energy for pure and $\mathrm{Al}$ doped samples

The absorption coefficient $\alpha$ is calculated by, $\alpha=2.303 \ln (\mathrm{A} / \mathrm{t})$, and the optical band gap $\mathrm{E}_{\mathrm{g}}$ is obtained using Taucs equation [109-110];

$$
(\alpha h v)^{\frac{1}{m}}=A\left(h v-E_{g}\right)
$$

where $m$ represents transition in the semiconducting materials and has values of $1 / 2$ and 2 for allowed direct and indirect transitions, respectively, and $\mathrm{B}$ is a constant that indicates the disorder state in the materials as well as the probability of the electronic transition mechanism. $\alpha$ is the absorption coefficient which is given by ; $\alpha=2.303 \frac{\mathrm{A}}{\mathrm{d}}$ where $\mathrm{A}$ is the absorbance and $\mathrm{d}$ is the diameter of glass cuvette. The plot of $(\alpha h v)^{2}$ against the photon energy is used to get the value of the optical direct band gap (see Figure 5 ). 
As shown in the figure, two absorption edges are observed for all samples, indicating that there are two direct electronic transitions due to absorption of the photon energy. The values of $\mathrm{E}_{\mathrm{g}}$ are obtained from the Figure are summarized in Table 3. The first $\left(\mathrm{E}_{\mathrm{gh}}\right)$ is obtained at UV region, while the second one $\left(\mathrm{E}_{\mathrm{gl}}\right)$ is obtained at visible region. The values of $\mathrm{E}_{\mathrm{gh}}$ and $\mathrm{E}_{\mathrm{gl}}$ are 3.60, 3.56, $3.43,3.53,3.68 \mathrm{eV}$ and 3.02, 2.95, 2.85, 2.92, $3.07 \mathrm{eV}$ respectively. This suggests both $\mathrm{E}_{\mathrm{gh}}$, and $\mathrm{E}_{\mathrm{gl}}$ had similar behavior as the $\mathrm{x}$ increased to 0.20. It is also evident from Table 2 that $\Delta \mathrm{E}=\left(\mathrm{E}_{\mathrm{gh}}\right.$ $-\mathrm{E}_{\mathrm{gl}}$ ) is $0.58,0.61,0.58,0.61$ and $0.61 \mathrm{eV}$ for all samples, in which $\Delta \mathrm{E}$ is constant. Anyhow, two $\mathrm{E}_{\mathrm{g}}$ are also recorded for n-type semiconductors [113-116]. In that case, the doping of $\mathrm{ZnO}$ with Al may produce high carrier concentration and, as a result, more conduction band states are blocked, which causes an increase, which, in turn, causes an increment in $\mathrm{E}_{\mathrm{g}}$ as obtained. However, the increment of $\mathrm{E}_{\mathrm{g}}$ above $\mathrm{x}=0.05$ may be due to the formation of some defects in the host materials, thereby creating insulating states in the forbidden gap inside the band structure.

Table 3: $\lambda, E_{\text {ex }}, E_{g}, \epsilon_{L},\left(N / m^{*}\right), N$ and $R$ for the samples

\begin{tabular}{|c|c|c|c|c|c|c|c|c|c|}
\hline $\mathbf{x}$ & $\begin{array}{c}\lambda(\mathbf{1}) \\
\mathbf{m a x} \\
(\mathbf{n m})\end{array}$ & $\begin{array}{c}\lambda(\mathbf{2}) \\
\mathbf{m a x} \\
(\mathbf{n m})\end{array}$ & $\begin{array}{c}\mathbf{E}_{\mathbf{e x}} \\
(\mathbf{1}) \\
(\mathbf{e V})\end{array}$ & $\begin{array}{c}\mathbf{E}_{\mathbf{e x}} \\
(\mathbf{2}) \\
(\mathbf{e V})\end{array}$ & $\begin{array}{c}\mathbf{E}_{\mathbf{g h}} \\
\mathbf{( e V})\end{array}$ & $\begin{array}{c}\mathbf{E}_{\mathrm{gL}} \\
(\mathbf{e V})\end{array}$ & $\mathbf{\epsilon}_{\mathbf{L}}$ & $\begin{array}{c}\mathbf{( N / \mathbf { m } ^ { * } )} \\
\times \mathbf{1 0}^{\mathbf{5 4}} \\
\left(\mathbf{g . c m}^{-3}\right)\end{array}$ & $\begin{array}{c}\mathbf{R} \\
\times \mathbf{1 0}^{-\mathbf{1 1}} \\
(\mathbf{c m})\end{array}$ \\
\hline 0.00 & 314 & 352 & 3.953 & 3.526 & 3.60 & 3.02 & 8.78 & 2.64 & 8.77 \\
\hline 0.025 & 314 & 364 & 3.953 & 3.410 & 3.56 & 2.95 & 5.06 & 3.01 & 8.40 \\
\hline 0.05 & 314 & 350 & 3.953 & 3.547 & 3.43 & 2.85 & 4.04 & 3.51 & 7.98 \\
\hline 0.10 & 314 & 344 & 3.953 & 3.608 & 3.53 & 2.92 & 3.48 & 3.81 & 7.76 \\
\hline 0.20 & 314 & 346 & 3.953 & 3.588 & 3.68 & 3.07 & 9.37 & 18.45 & 4.59 \\
\hline
\end{tabular}

In addition, the high frequency dielectric constant of $\mathrm{Zn}_{1-\mathrm{x}} \mathrm{Al}_{\mathrm{x}} \mathrm{O}$ is calculated from the following relation, which represents the dependence of the reflective index $n$ on the wavelength $\lambda[\mathbf{1 1 7 -}$ 120]:

$$
n^{2}=€_{L}-\left(\frac{e^{2}}{4 \pi^{2} c^{2} \varepsilon_{0}}\right)\left(\frac{N}{m^{*}}\right) \lambda^{2}
$$

where $\mathrm{c}, \mathrm{e}, \mathrm{m}^{*}, \epsilon_{\mathrm{L}}$ and $\mathrm{N}$ denote light speed, electron charge, free space permittivity, effective mass of electron, residual lattice dielectric constant and free carrier concentration, respectively. The intercept and slope of the straight lines in Figure 6 give the values of $€_{\mathrm{L}}$ and N/m* which are listed in Table 3 are slightly increased by $\mathrm{x}$ up to $\mathrm{x}=0.10$, followed by a sharp increase at $\mathrm{x}=$ 0.20 , whereas $€_{\mathrm{L}}$ is decreased to $\mathrm{x}=0.10$, followed by a sharp increase at $\mathrm{x}=0.20$. The interatomic distance $(\mathrm{R})$ given by $\left(0.86 / \mathrm{N}^{(1 / 3)}\right)[121-122]$ and listed in Table 3 is decreases as $\mathrm{x}$ increases to 0.20. Based on the above results, the higher valence state of the $\mathrm{Al}^{3+}$ compared to $\mathrm{Zn}^{2+}$ led to slightly deeper donors and, consequently, more carriers are generated. Further, and in parallel, the ability of electron migration may be enhanced [123-124]. Furthermore, $\mathrm{Al}$ is nearly non-magnetic, and the addition of $\mathrm{Al}$ beside $\mathrm{Zn}$ will decrease the localization of the carriers, and therefore, we strongly recommend the Al doped samples for optoelectronic applications. 


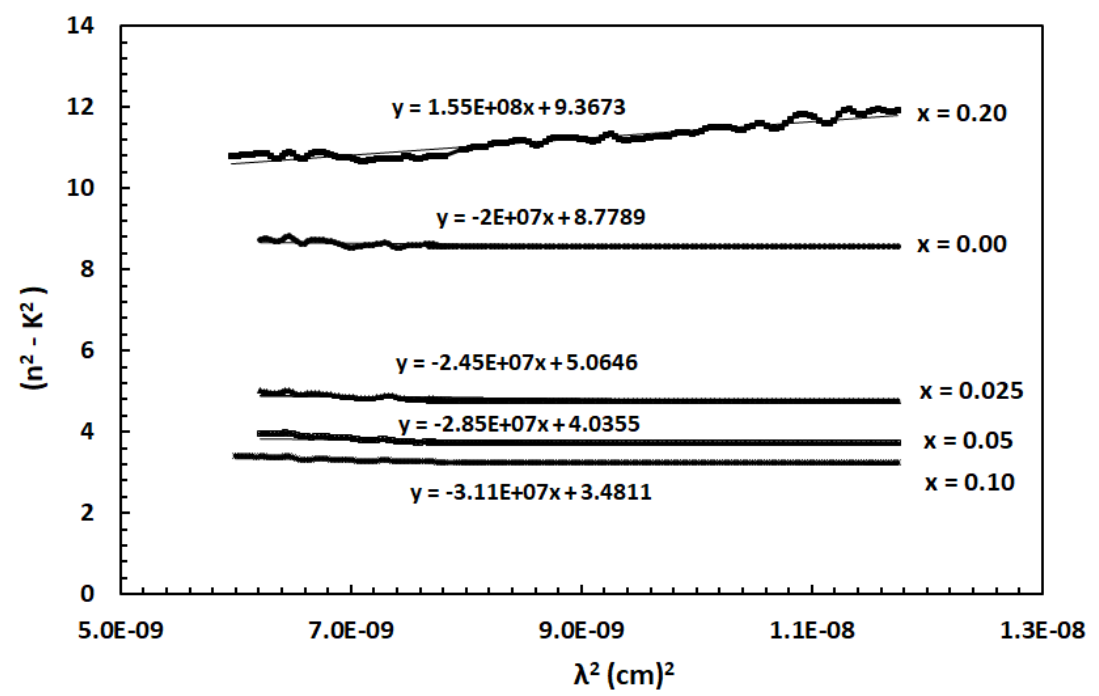

Figure 6: Real part of optical dialectic constant $\left(\mathrm{n}^{2}-\mathrm{k}^{2}\right)$ versus wave length for pure and $\mathrm{Al}$ doped samples

\section{4- Dielectric Measurements}

The real $\varepsilon^{\prime}$ part of the sample dielectric constant is determined by using the relation [125-127];

$$
\varepsilon^{\prime}=\frac{C d}{\varepsilon_{\mathrm{o}} A}
$$

Where $C$ is the capacitance of the sample and $C_{0}$ is the empty cell capacitance $\left(C_{0}=\varepsilon_{0} A / d\right), d$ is the sample thickness, $A$ is the surface area of the electrodes, $\varepsilon_{0}=8.85 \times 10^{-12}(\mathrm{~F} / \mathrm{m})$ is the permittivity of free space. Figure 7 shows the plot of $\varepsilon^{\prime}$ against $\mathrm{f}$ for all samples. It is clear that $\varepsilon^{\prime}$ is gradually decreased as f increases up to $10^{4} \mathrm{~Hz}$ for all samples, and above that it decreases, and then saturated at $10^{7} \mathrm{~Hz}$. In addition, it is slightly increased as $\mathrm{x}$ increases up to 0.0 .025 , but there is a significant increase with further increase of $x$ above 0.025 . For example, $\varepsilon^{\prime}$ of $x=0.20$ is at least about $10^{3}$ times of $\mathrm{x}=0.00$, which indicates that the addition of $\mathrm{Al}$ above 0.025 to $\mathrm{Zn}$ shifts the dielectric medium to higher values. Therefore, when a field is applied, the charge carriers can easily move within the grains at a low f below $10 \mathrm{MHz}$, but they are accumulated at the grain boundaries, resulting in the $\mathrm{ZnO}$ large interfacial polarization, and in turn, high $\varepsilon^{\prime}$. With a rise in frequency above $10 \mathrm{MHz}$, a decrease of $\varepsilon^{\prime}$ could be obtained. This is due to the fact that any species contributing to polarization is found to lag behind the applied field, and consequently, the dipoles cannot follow the ac field [128-130]. On the other hand, the increase of $\varepsilon^{\prime}$ with $\mathrm{x}$ can be explained in terms of increasing electro-negatively between $\mathrm{Al}$ and $\mathrm{O}$, which is 1.83 instead of 1.79 between $\mathrm{Zn}$ and $\mathrm{O}$, and also increasing the number of carriers as indicted above [131-133]. Due to this, the strength of the Al-O ionic bond is improved, which results in increasing the dielectric polarization. Moreover, the decrease of crystallite size and average crystalline size leads to an increase in the number of dipoles, which results in a decrease in polarization and increases the $\varepsilon^{\prime}$ values for the doped samples as reported [134-135]. 


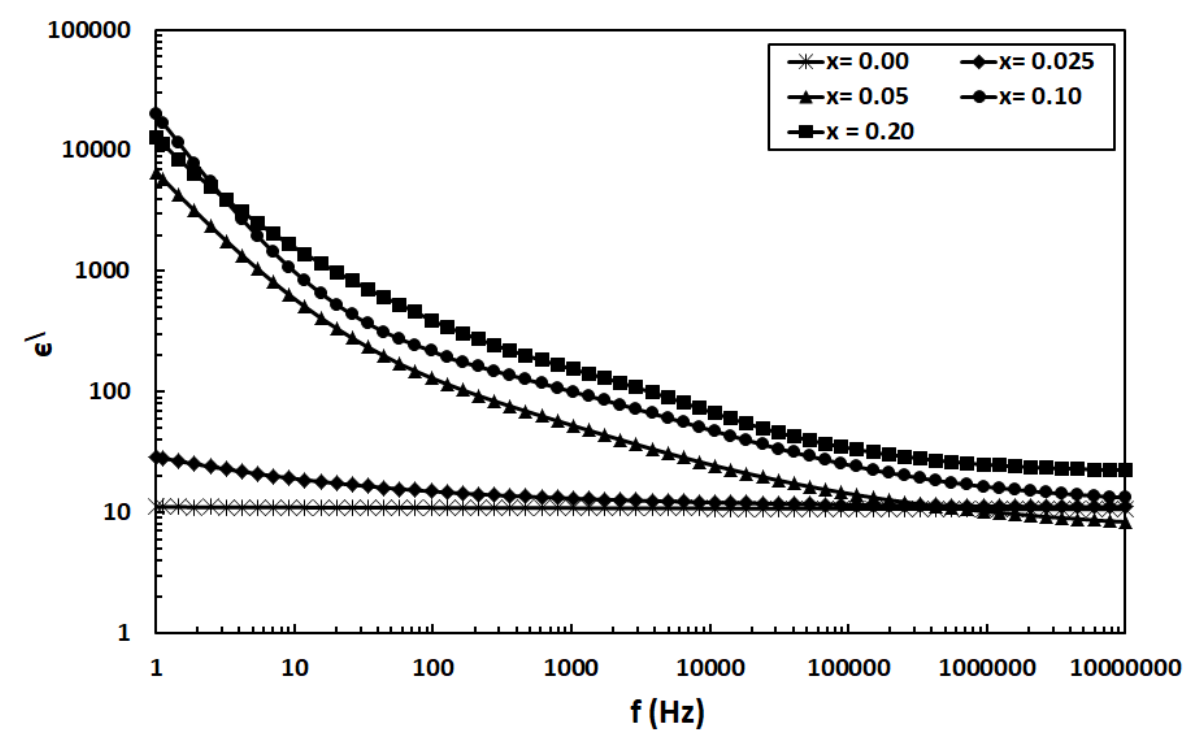

Figure 7: Real part of dialectic constant $\left(\varepsilon^{\prime}\right)$ versus frequency for pure and $\mathrm{Al}$ doped samples

The total conductivity can be obtained by [136];

$$
\sigma_{t}(\omega)=\sigma_{d c}+\sigma_{a c}=\sigma_{d c}+B \omega^{s}
$$

Where $\sigma_{\mathrm{dc}}$ is the dc conductivity calculated at $0 \mathrm{f}, \mathrm{B}$ is constant and $\mathrm{s}$ is the exponent of frequency. Figure 8 shows the real part $\left(\sigma^{\prime}\right)$ of $\sigma_{\mathrm{ac}}$ as a function of $\mathrm{f}$. It is evident from the figure that $\sigma^{\prime}$ gradually increases by increasing f for all samples up to $10 \mathrm{MHz}$, obeying the universal power law [137]. In addition, $\sigma^{\prime}$ for Al-doped samples is higher than that of $\mathrm{ZnO}$ due to the increased charge carriers through the replacement of $\mathrm{Zn}^{2}$ by $\mathrm{Al}^{3+}$ [55-57]. At low $\mathrm{f}$, the field drift carries over a large distance, and therefore $\sigma \backslash$ is almost unchanged. As $f$ is raised, the displacement of the carriers is reduced, and at a critical frequency $\omega_{\mathrm{p}}$, the $\sigma^{\prime}$ follows the law $\left(\sigma_{\mathrm{ac}}\right.$ $\left.\sim \omega^{\mathrm{s}}\right)$ with $(0 \leq \mathrm{s} \leq 1)$ characterizing hopping conduction [138-139]. These outcomes indicate that the addition of $\mathrm{Al}$ supports the $\sigma_{\mathrm{ac}}$ of $\mathrm{ZnO}$ as obtained.

However, the linear fit between $\ln \sigma^{\prime}$ and $\ln \omega$ shown in Figure $9(\mathrm{a}, \mathrm{b})$ gives two different linear regions. The obtained values of $\mathrm{s}$ and $\mathrm{B}$ at low and high frequencies named as $\mathrm{s}_{\mathrm{L}}, \mathrm{Sh}_{\mathrm{h}}, \mathrm{B}_{\mathrm{h}}$ and $\mathrm{B}_{\mathrm{L}}$ are obtained and listed in Table 4. The values of $\mathrm{S}_{\mathrm{L}}$ are between 0.565 and 0.898 for $\mathrm{x}=0.00$ and 0.025 samples, which indicates electronic conduction. But with increasing $\mathrm{x}$ above 0.025 , the values of $\mathrm{s}_{\mathrm{L}}$ are $0.023,0.031$ and 0.011 , which indicates hole conduction. However, similar behavior is obtained for $\mathrm{S}_{\mathrm{h}}$. This behavior is attributed to the excess number of hole carriers which may be generated as a result of the difference between $\mathrm{Zn}^{2+}$ and $\mathrm{Al}^{3+}$. 


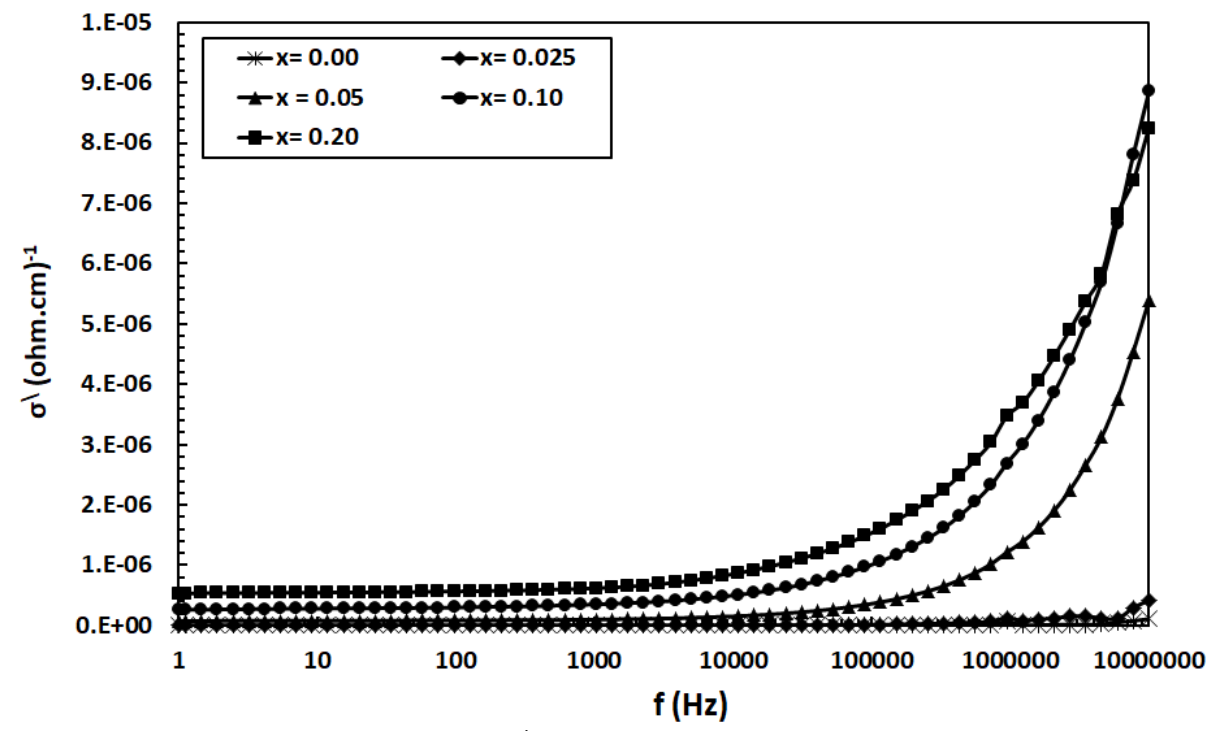

Figure 8: Real part of conductivity $\left(\sigma^{\prime}\right)$ versus frequency for pure and Al doped samples

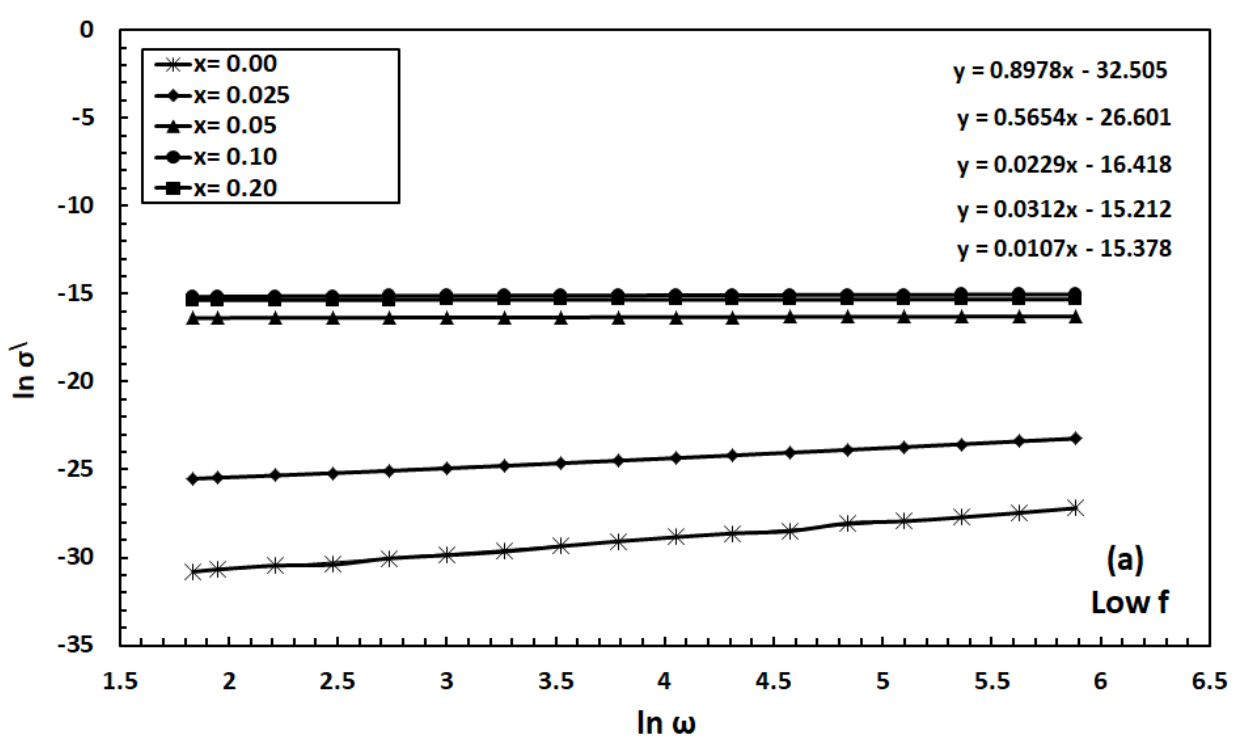

Figure 9 (a): $\ln \sigma^{\prime}$ versus $\ln \omega$ at low frequency for pure and $\mathrm{Al}$ doped samples

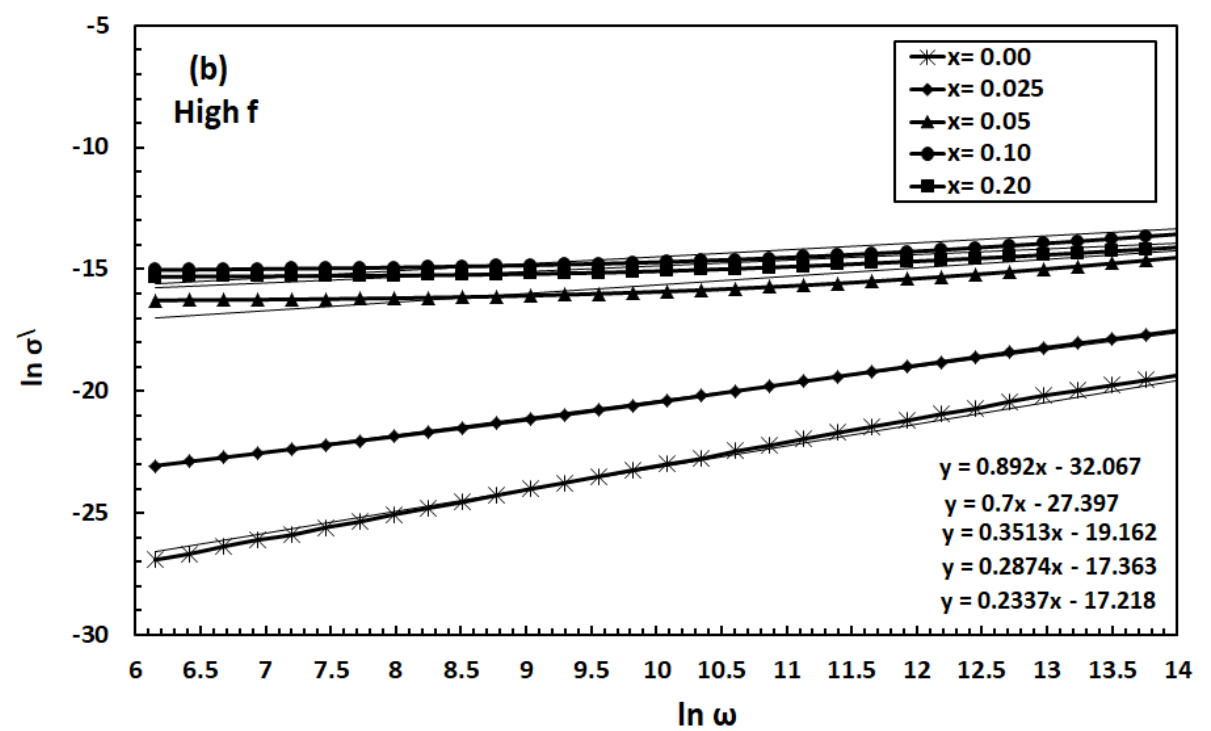

Figure 9(b): $\ln \sigma^{\prime}$ versus $\ln \omega$ at high frequency for pure and $\mathrm{Al}$ doped samples 
Table 4: $\mathrm{S}, \mathrm{B}$ and $\mathrm{W}_{\mathrm{m}}$ for pure and doped samples

\begin{tabular}{|c|c|c|c|c|c|c|c|}
\hline $\begin{array}{c}\text { Al } \\
\mathbf{c o n t e n t} \\
\mathbf{x}\end{array}$ & $\begin{array}{c}\boldsymbol{\sigma}_{\text {dc }} \\
\left(\mathbf{\Omega . c m} \mathbf{. 1}^{-1}\right.\end{array}$ & $\mathbf{S}_{\mathbf{L}}$ & $\mathbf{S}_{\mathbf{h}}$ & $\mathbf{B}_{\mathbf{L}}$ & $\mathbf{B}_{\mathbf{h}}$ & $\begin{array}{c}\mathbf{W}_{\mathbf{m L}} \\
(\mathbf{e V})\end{array}$ & $\begin{array}{c}\mathbf{W}_{\mathbf{m h}} \\
(\mathbf{e V})\end{array}$ \\
\hline 0.00 & $3 . \mathrm{E}-11$ & 0.898 & 0.892 & $7.64 \mathrm{E}+15$ & $1.18 \mathrm{E}+14$ & 1.520 & 1.435 \\
\hline 0.025 & $2 . \mathrm{E}-10$ & 0.565 & 0.700 & $2.80 \mathrm{E}+12$ & $1.26 \mathrm{E}+12$ & 0.356 & 0.517 \\
\hline 0.05 & $8 . \mathrm{E}-08$ & 0.023 & 0.351 & $7.41 \mathrm{E}+08$ & $4.76 \mathrm{E}+09$ & 0.159 & 0.239 \\
\hline 0.10 & $7 . \mathrm{E}-08$ & 0.031 & 0.287 & $2.43 \mathrm{E}+07$ & $2.88 \mathrm{E}+08$ & 0.160 & 0.217 \\
\hline 0.20 & $6 . \mathrm{E}-08$ & 0.011 & 0.234 & $2.10 \mathrm{E}+07$ & $3.33 \mathrm{E}+08$ & 0.157 & 0.202 \\
\hline
\end{tabular}

According to correlated barrier hopping $(\mathrm{CBH})$ model, the binding energy $\mathrm{W}_{\mathrm{m}}$, is given by [140];

$$
s=1-\frac{6 K_{B} T}{W_{m}+K_{B} T \ln \omega \tau_{\mathrm{o}}}=1-\frac{6 K_{B} T}{W_{m}}
$$

Where $\tau_{0}$ is the characteristic relaxation time and is in the order of the atomic vibration of $10^{-13} \mathrm{~s}$. The values of $\mathrm{W}_{\mathrm{m}}$ correlated with the range of $\mathrm{f}$ are listed in Table 4. Although they are decrease with $\mathrm{x}$, the $\mathrm{W}_{\mathrm{mh}} \approx 1.5 \mathrm{~W}_{\mathrm{mL}}$ except for $\mathrm{x}=0.00$ in which $\mathrm{W}_{\mathrm{mh}} \approx 0.94 \mathrm{~W}_{\mathrm{mL}}$. In addition, the minimum hopping distance $\left(\mathrm{R}_{\min }\right)$ is given by [141];

$$
R_{\min }(\omega)=\frac{e^{2}}{\pi \varepsilon_{\mathrm{o}} \varepsilon^{\prime}\left(W_{m}+K_{B} T \ln \omega \tau_{\mathrm{o}}\right)} \sim \frac{e^{2}}{\pi \varepsilon_{\mathrm{o}} \varepsilon^{\prime} \bar{W}_{m}}
$$

Where $\bar{W}_{m}=\left[\left(\mathrm{W}_{\mathrm{mL}}+\mathrm{W}_{\mathrm{mh}}\right) / 2\right]$. On the other hand, the density of localized states at which carriers exist $\mathrm{N}$ can be expressed by [142];

$$
N(\omega)=\frac{24 \sigma^{\prime}}{\pi^{3} \varepsilon_{\mathrm{o}} \varepsilon^{\prime} \omega R_{\min }^{6}}
$$

As shown in Figure 10 (a), the unusual behavior of $\mathrm{R}_{\min }$ can be classified into two series relative to $x=0.00$. The vice is versa for the behavior of $N(\omega)$ against the $x$, see Figure 10 (b). These results indicate that the $\mathrm{R}_{\min }$ mechanism against $\mathrm{f}$ is controlled by the $\mathrm{x}$ in the low under doped region $(\mathrm{x}=0.025)$ and also in the over-doped region $(\mathrm{x}=0.20)$.

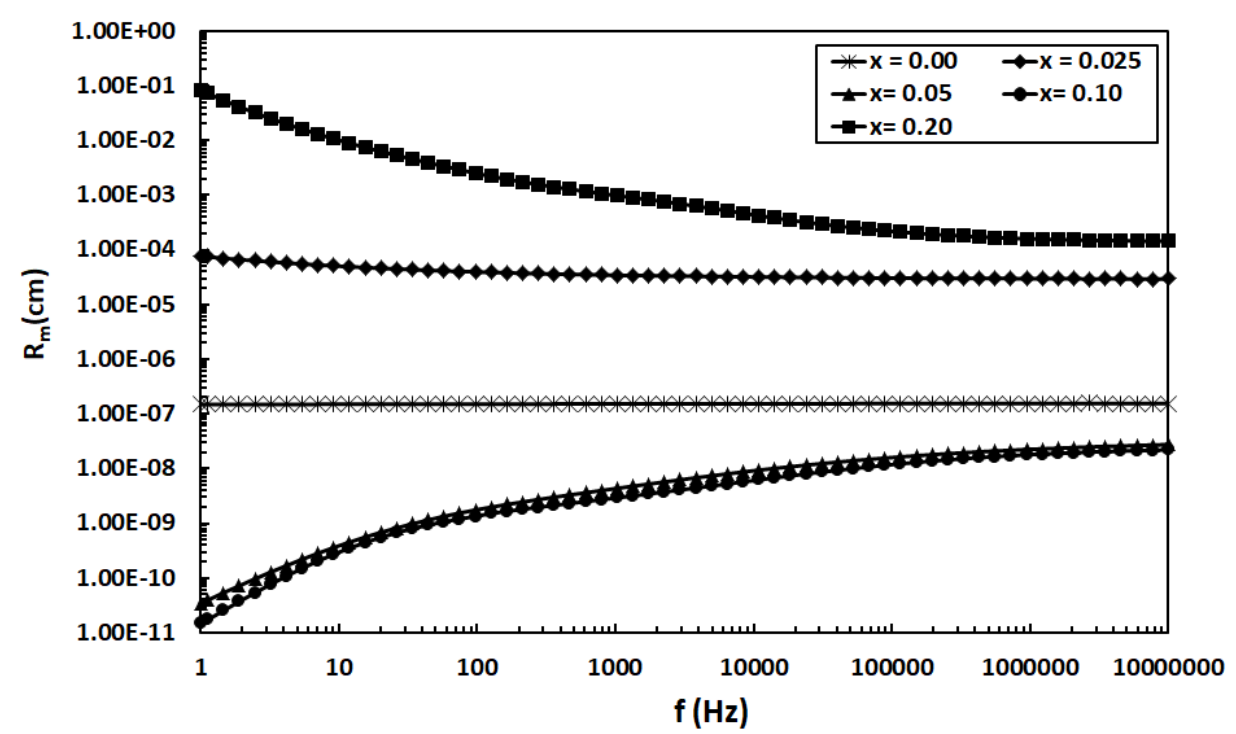

Figure 10 (a): Hopping distance $\left(\mathrm{R}_{\min }\right)$ versus frequency for pure and $\mathrm{Al}$ doped samples 


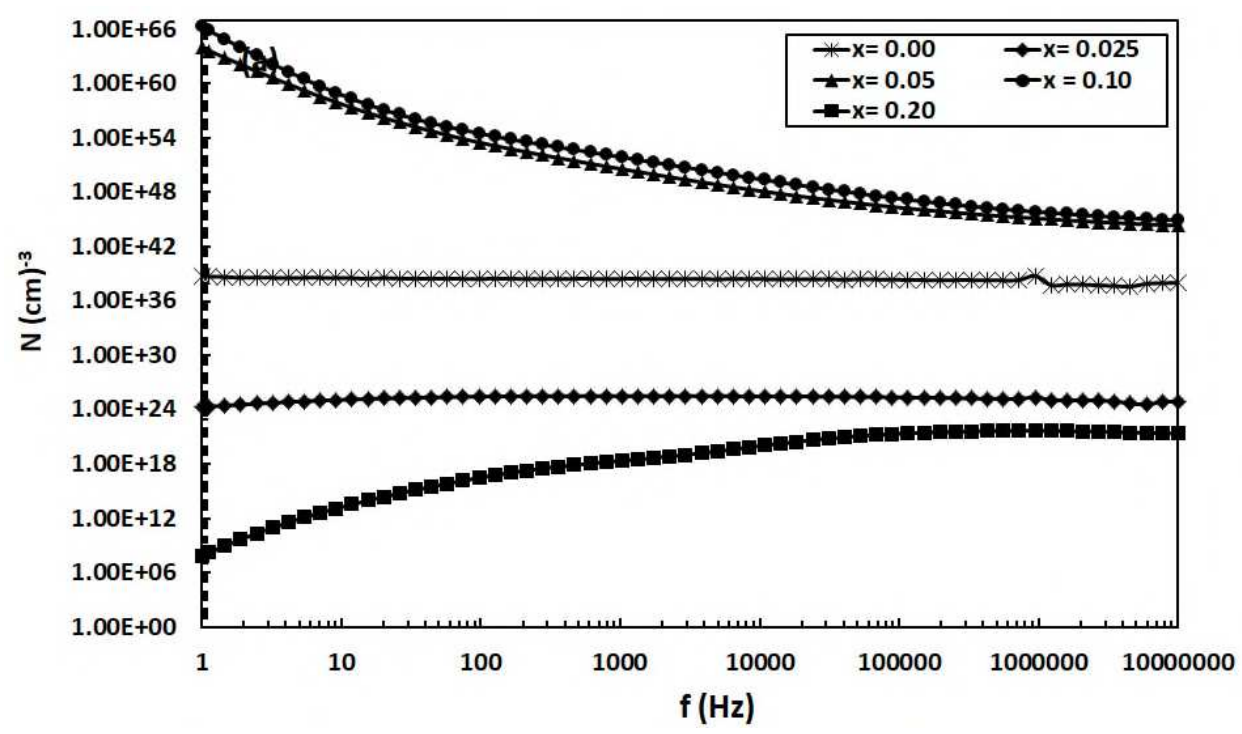

Figure 10 (b): Density of localized states (N) versus frequency for pure and Al doped samples

In addition, the density of states at Fermi level $\mathrm{N}\left(\mathrm{E}_{\mathrm{f}}\right)$ can be calculated by $[\mathbf{1 4 3}]$;

$$
N_{E_{f}}(\omega)=\sqrt{\frac{3 \sigma^{\prime} \alpha^{5}}{4 e^{2} \omega K_{B} T\left(\ln \frac{10^{13}}{\omega}\right)^{2}}}
$$

Where $\alpha$ is the localized wave function and equals $10^{10} \mathrm{~m}^{-1}$ and $\mathrm{f}_{\mathrm{o}}=10^{13} \mathrm{~Hz}$ is the photon frequency corresponding to the applied ac field. However, the behavior of $N\left(E_{f}\right)$ against $x$ shown in Figure 11(a) seems to be systematic because $N\left(E_{f}\right)$ is gradually increased as $x$ increases to 0.20 . But it has unusual behavior against $f$ where it gradually increases with $f$ for $x=0.00$ and 0.025 samples, goes to optimum and then decreases. But with increasing $x$ above $0.025, \mathrm{~N}\left(\mathrm{E}_{\mathrm{f}}\right)$ decreases, increases and goes to an optimum and then decreases. The increase in $N\left(E_{F}\right)$ against $x$ confirms the increase in $\sigma_{\mathrm{ac}}$, and may support the growing concentration of defect energy states in $\mathrm{ZnO}$ [144]. Our interesting point here is the optimum values of $\mathrm{N}\left(\mathrm{E}_{\mathrm{F}}\right)$ obtained at about 195 $\mathrm{KHz}$ for all samples and also its dependence on $\mathrm{x}$. For example, $\mathrm{N}\left(\mathrm{E}_{\mathrm{F}}\right)$ was increased from 8.05 $\mathrm{x} 10^{19}\left(\mathrm{erg} . \mathrm{cm}^{3}\right)^{-1}$ for $\mathrm{x}=0.00$ to $2.01 \times 10^{20}, 8.97 \times 10^{20}, 1.75 \times 10^{21}$ and $1.78 \times 10^{21}\left(\mathrm{erg} . \mathrm{cm}^{3}\right)^{-1}$ for the doped samples, respectively. This behavior is not clear to us at present and may be either related to the resonance of lattice vibrations against ac field/or the enhancement of ac conductivity at $195 \mathrm{KHz}$. The higher value of $\mathrm{F}$, as a figure of merit given by, $\left(\sigma_{\mathrm{ac}} / \varepsilon^{1}\right)$ is mainly good indicator for a sample to be more suitable for solar cell applications [145-146]. As shown in Figure 11(b), the $\mathrm{F}$ factor is gradually increased by increasing $\mathrm{x}$, but it is almost constant above $\mathrm{x}=0.05$. These results strongly recommend the Al doped samples up to $\mathrm{x}=0.10$ for solar cell design. 


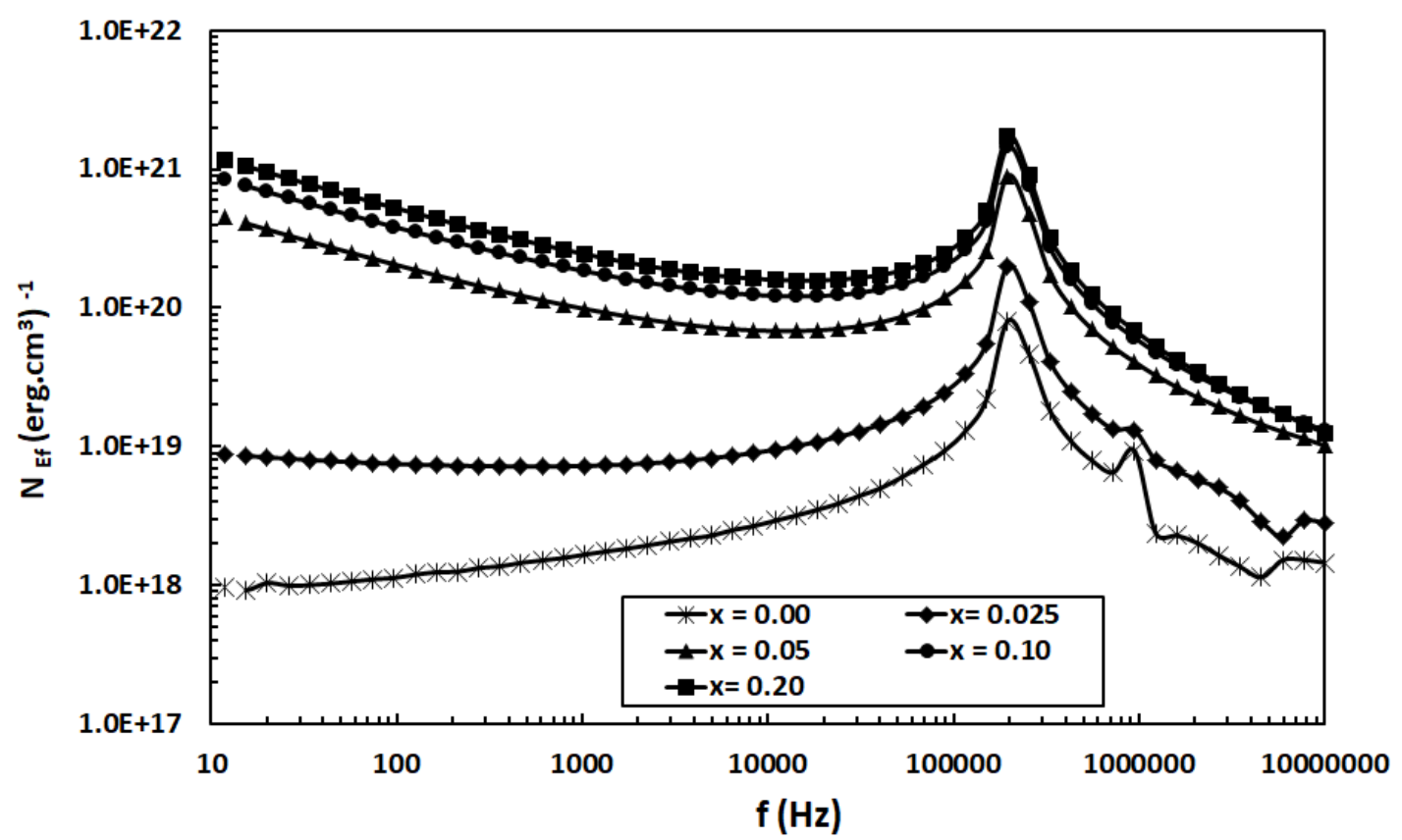

Figure 11(a): Density of states at Fermi level $N\left(E_{f}\right)$ versus frequency for the samples

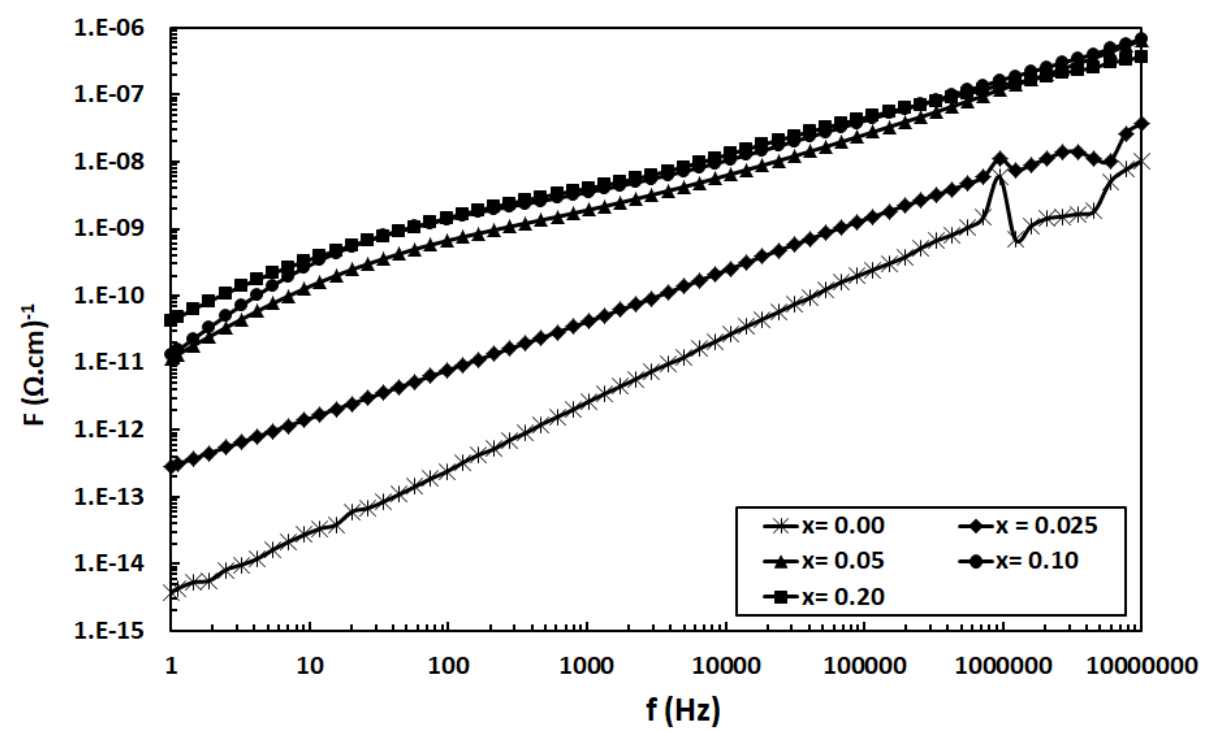

Figure 11(b): F-factor versus frequency for the samples

Figure $12(\mathrm{a}, \mathrm{b})$ shows the variations of $\mathrm{Z} \backslash$ and $\mathrm{Z}^{\|}$against $\mathrm{f}$ for all samples. It is evident that $\mathrm{Z}$ and $Z \|$ for $x \leq 0.025$ samples are decreased linearly as a straight line with a rise in $\mathrm{f}$. In addition, $Z^{\backslash}$ was also decreased as $\mathrm{x}$ increases, whereas $Z^{\|}$was increased. With further increase of $\mathrm{x}$ above $0.025, \mathrm{Z}^{\backslash}$ is slightly increased with $\mathrm{f}$ and goes to higher values at about $10 \mathrm{KHz}$, and then decreases at $10 \mathrm{MHz}$. It is also decreases as $\mathrm{x}$ increases below $100 \mathrm{KHz}$, but above that it is nearly constant for all samples. In contrast, a little bit decrease is obtained below $10 \mathrm{KHz}$ for $\mathrm{Z}^{\|}$ against $f$ followed by a significant increase with the rise in $f$ to $10 \mathrm{MHz}$, but it becomes higher than that of $\mathrm{x} \leq 0.025$ samples. However, the increases of $\mathrm{Z}$ at low $\mathrm{f}$ confirm the highly resistive grain boundaries, whereas the decrease is due to the rise in the hopping of charge carriers.[147150]. Anyhow, the Cole- Cole plot is shown in Figure $13(\mathrm{a}, \mathrm{b})$ and the impedance of grains and grain boundaries is determined at the half and the end of semicircle-shape plot, respectively. It is evident that the impedance spectra of $\mathrm{x}=0.00$ sample is straight line like- shape with $\mathrm{Z}^{\backslash}=$ $2.05 \times 10^{10} \Omega$ ) and $Z^{\|}=1.39 \times 10^{8} \Omega$. With increasing $x$ to 0.025 , it becomes half semicircle (one 
quarter) like-shape, and with more increase of $\mathrm{x}$ to 0.05 , a complete semicircle like-shape with large radius is obtained. Similar behavior is also obtained for $x \geq 0.10$, but the area of semicircle is gradually decreased as $\mathrm{x}$ increases. However, the values of the impedance of grain and grain boundaries for all doped samples $Z^{\prime}(g), Z^{\prime}(g b), Z^{\prime}(g)$ and $Z^{\prime \prime}(g b)$ are listed in Table 5, in which they are gradually decreased as $x$ increases to 0.20 .

Table 5: $\mathrm{Z}$ and $\mathrm{Z}^{\|}$for grain and grain boundaries for pure and $\mathrm{Al}$ doped samples

\begin{tabular}{|c|c|c|c|c|}
\hline $\mathbf{x}$ & $\begin{array}{c}\mathrm{Z}^{\prime}(\mathbf{g}) \\
(\boldsymbol{\Omega})\end{array}$ & $\begin{array}{c}\mathrm{Z}^{\prime} \mathbf{g} \\
(\boldsymbol{\Omega})\end{array}$ & $\begin{array}{c}\mathrm{Z}^{\prime}(\mathbf{g b}) \\
(\mathbf{\Omega})\end{array}$ & $\begin{array}{c}\mathrm{Z}^{\prime} \mathbf{g b} \\
(\mathbf{\Omega})\end{array}$ \\
\hline 0.00 & ------- & ------- & ------- & ------- \\
\hline 0.025 & $3.19 \times 10^{9}$ & $6.19 \times 10^{9}$ & $6.38 \times 10^{9}$ & $4.92 \times 10^{8}$ \\
\hline 0.05 & $4.59 \times 10^{5}$ & $2.65 \times 10^{5}$ & $10.02 \times 10^{5}$ & $4.15 \times 10^{4}$ \\
\hline 0.10 & $3.01 \times 10^{5}$ & $1.65 \times 10^{5}$ & $6.01 \times 10^{5}$ & $1.56 \times 10^{4}$ \\
\hline 0.20 & $1.88 \times 10^{5}$ & $1.05 \times 10^{5}$ & $4.41 \times 10^{5}$ & $1.13 \times 10^{4}$ \\
\hline
\end{tabular}

It is seen that the applied frequency for a pure sample is not sufficient to cover the grain boundary, and therefore the $Z^{\prime}(\mathrm{g})$ and $Z^{\prime}(\mathrm{gb})$ cannot be evaluated. By increasing $\mathrm{x}$ to 0.025 , the $Z^{\prime}(\mathrm{gb})$ was reduced, and the frequency was able to make it as one quarter of a circle because the $\mathrm{Z}^{\prime}(\mathrm{gb})$ was reduced, and it can be obtained approximately. With an increase of $\mathrm{x}$ above 0.025 , the applied frequency is more than sufficient for covering the grain boundary, and therefore the $\mathrm{Z}^{\prime}(\mathrm{g})$ and $\mathrm{Z}^{\prime}(\mathrm{gb})$ could be evaluated. However, a single arc of an identical $\boldsymbol{\tau}=(1 / \boldsymbol{\omega})=\mathrm{RC}$ has been obtained in pure and doped $\mathrm{ZnO}$ [151-156]. Because of this behavior, conduction in grains and their boundaries could not be separated [157]. Other reports believed that a single arc was caused by the combined contributions of the grain's core resistive and grain boundary [158]. This fact suggests that the excess of doping probably exists in the grain boundary region, either as a very thin secondary phase, which could benefit the grain boundary transport for grain growth [159-161].

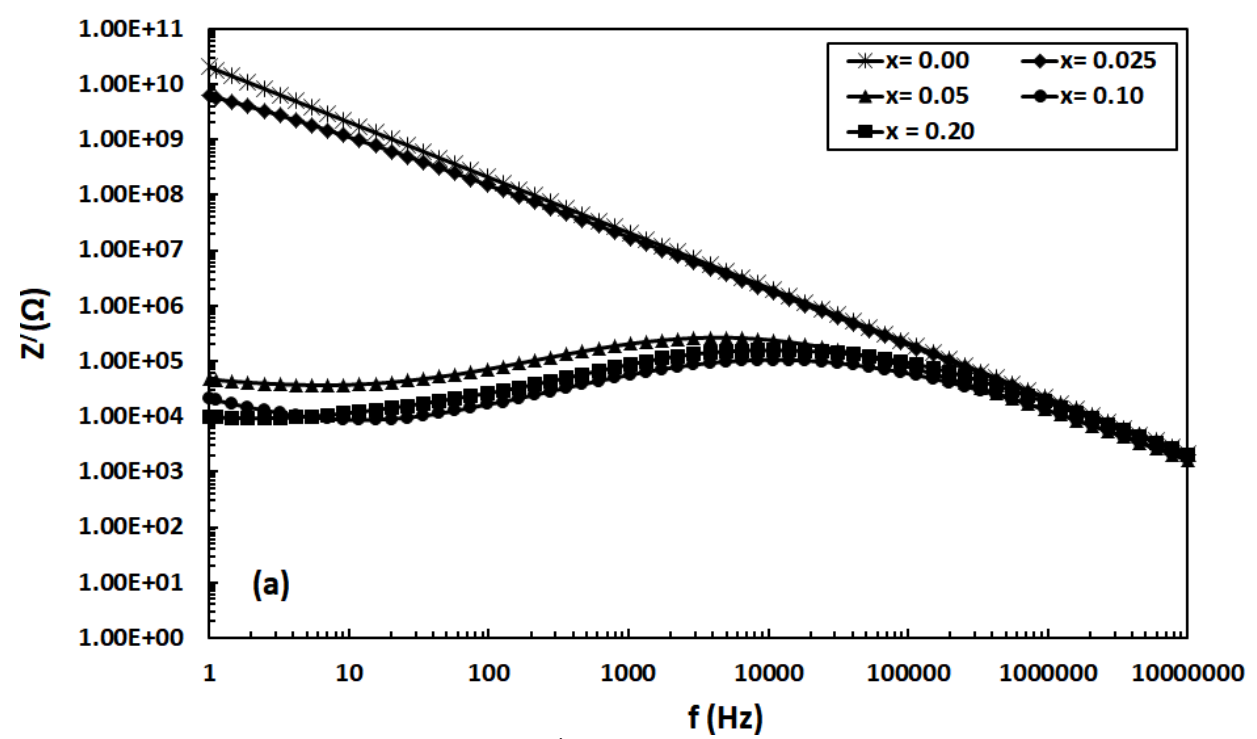

Figure 12 (a): Real part of impedance $(\mathrm{Z})$ versus frequency for pure and $\mathrm{Al}$ doped samples 


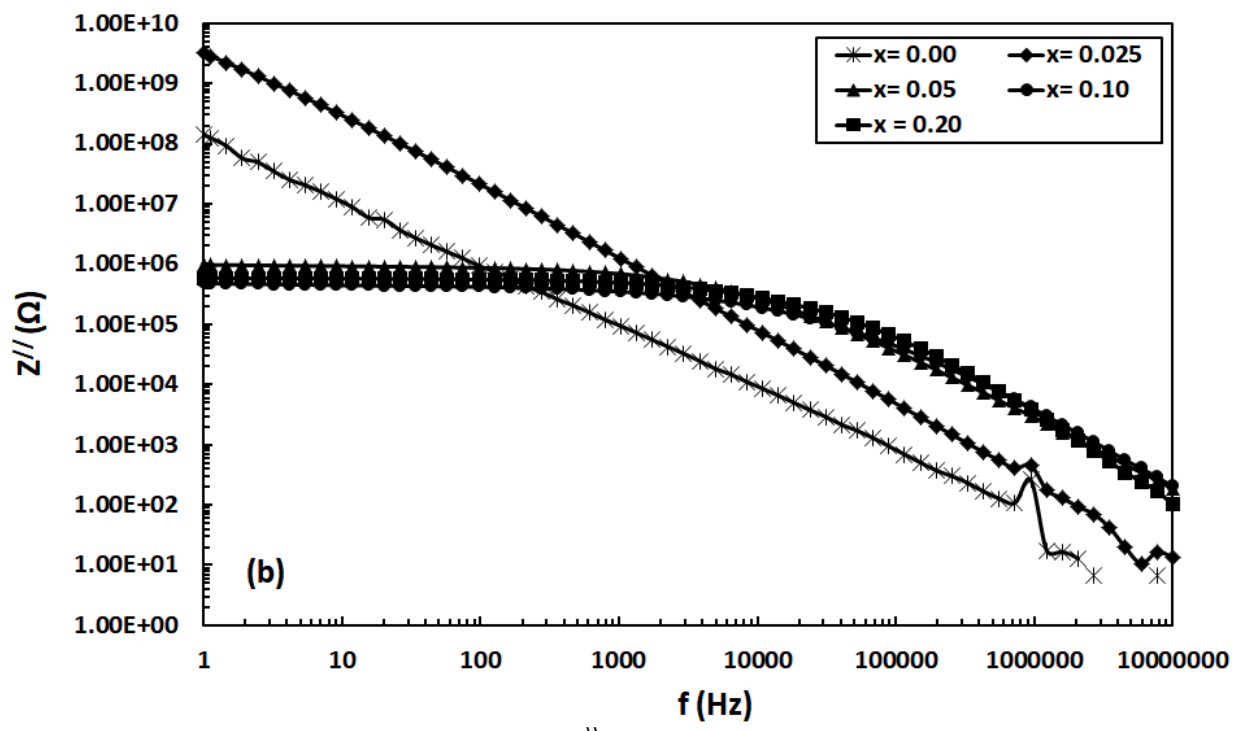

Figure 12 (b): Imaginary part of impedance $\left(Z^{\|}\right)$versus frequency for pure and Al doped samples

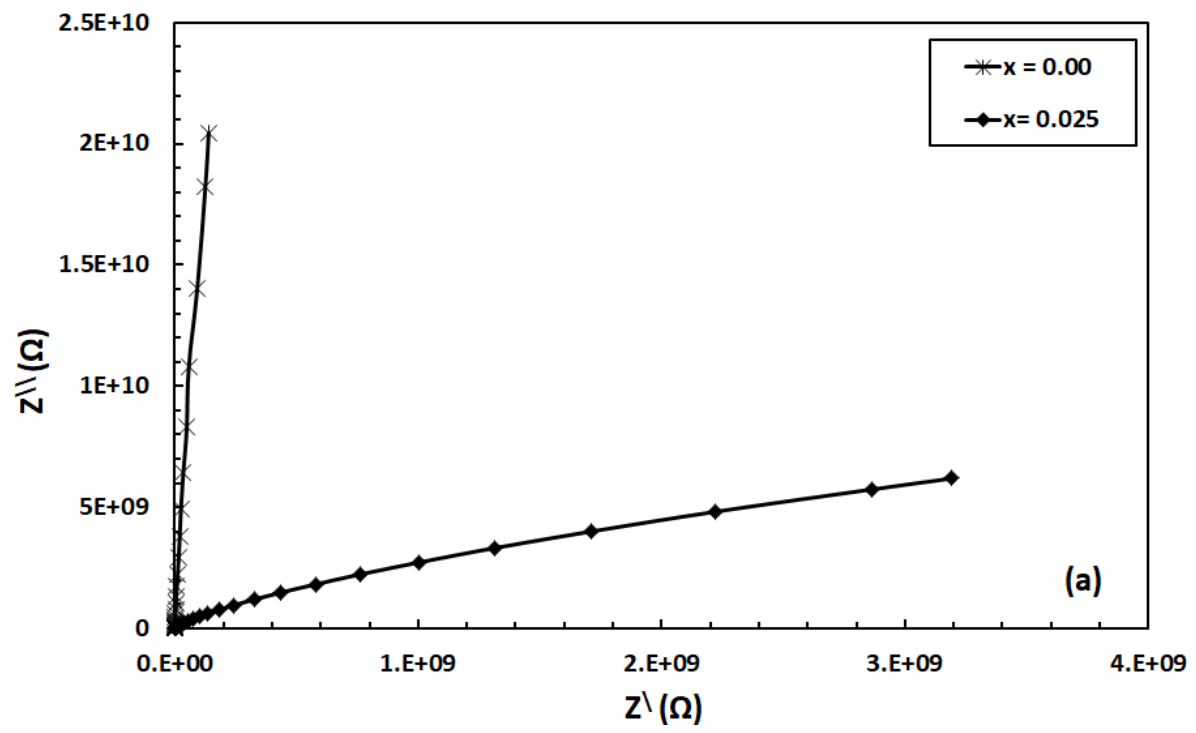

Figure 13 (a): The Cole- Cole plot for $\mathrm{x}=0.00$ and 0.025 samples

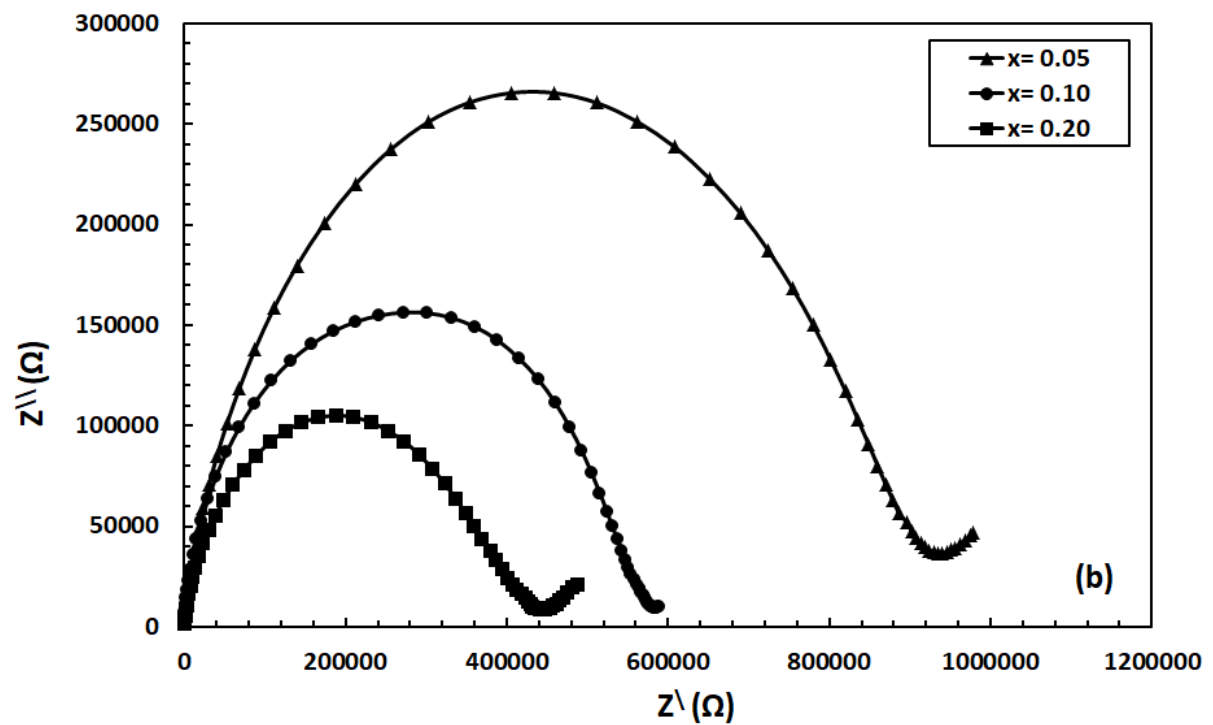

Figure 13 (b): The Cole- Cole plot for $\mathrm{x}=0.05,0.10$ and 0.20 samples 


\section{Conclusion}

Structural, FTIR, optical and dielectric properties of $\mathrm{Zn}_{1-\mathrm{x}} \mathrm{Al}_{\mathrm{x}} \mathrm{O}$ were investigated. Regardless of the $\mathrm{x}=0.20$ sample which show unusual behavior, the lattice constants, crystallite diameter, porosity, average crystalline size Debye temperature and elastic modulus are increased for the doped samples. The residual stress is compressive for the pure sample, but it is tensile for the doped samples. Although two different values of $\mathrm{E}_{\mathrm{g}}$ are apparent for each sample, the $\Delta \mathrm{E}=\left(\mathrm{E}_{\mathrm{gh}}\right.$ - $\mathrm{Egl}_{\mathrm{gl}}$ is almost constant. Further, the $\epsilon_{\mathrm{L}}$ decreased while $\left(\mathrm{N} / \mathrm{m}^{*}\right)$ was increased as $\mathrm{x}$ increases to 0.20 . On the other hand, the values of $\varepsilon^{\prime}$ and $\sigma^{\prime}$ are generally increased as $\mathrm{x}$ increases to 0.20 . The conduction is electronic for $\mathrm{x} \leq 0.025$ samples, but it is changed to hole for $\mathrm{x} \leq 0.20$. Although $\mathrm{W}_{\mathrm{m}}$ decreased by increasing $\mathrm{x}$, there was no exact trend for the behaviors of $\mathrm{R}_{\min }$ and $\mathrm{N}$ against $\mathrm{x}$. Interestingly, $\mathrm{N}\left(\mathrm{E}_{\mathrm{F}}\right)$ has an optimum value at $195 \mathrm{KHz}$ for all samples. The F-factor for solar cell design is increased as $\mathrm{x}$ increases to 0.10 , but it is almost constant at $\mathrm{x}=0.20$. The Cole-Cole plot for the samples is a straight line for $\mathrm{x}=0.00$, a semicircle arc for $\mathrm{x}=0.025$, and a complete semicircle for $x \geq 0.05$. The $Z^{\prime}(G)$ and $Z^{\prime}(\mathrm{GB})$ are gradually decreased by increasing $x$ to 0.20 . It is approved that the addition of $\mathrm{Al}$ to $\mathrm{ZnO}$ improves the mechanical, optical, and dielectric properties of $\mathrm{ZnO}$, and strongly recommended for the design of optoelectronic and solar cell instruments..

\section{Acknowledgment}

The authors extend their appreciation to the Deanship of Scientific Research at King Khalid University for funding this work through research groups program under grant number R.G.P. 2/137/42. They are also thanking Dr/Mohamed Mahmoud, KFU for his co-operation during dielectric measurements.

\section{Funding and/or Conflicts of interests/Competing interests}

The authors declare that they have no competing interests and the present work is original not published or submitted for evaluation to another Journal. Moreover, the obtained systematic findings or study strongly recommend the Al doped samples for advanced applications such as Optoelectronic and solar cell instruments, which probably have never been early reported elsewhere over the last 3-years, which and highlight the present investigation. In addition, the datasets generated during and/or analyzed during the submitted current study are only available from the corresponding author on reasonable request. 


\section{References}

1-Manikandan A, Manikandan E, Meenatchi B, Vadivel S, Jaganathan S K, Ladchumananandasivam R, Henini M, Maaza M and Aanand J S 2017 J. Alloy. Comp. 723 1155-61

2-Ragupathi C, Vijaya J J, Manikandan A and Kennedy L J 2013 J. Nanosci.Nanotechnol. 13 8298-306

3- Padmapriya G, Manikandan A, Krishnasamy V, Jaganathan S K and Antony S A 2016 J. Supercond. Nov. Magn 29 2141-9

4- Hazem Mahmoud Ali and Ahmed Mohamed Abdel Hakeem, Eur. Phys. J. Appl. Phys. 72, 10301(2015).

5- D.R. Clarke, J. Am. Ceram. Soc. 82 (3) (1999) 485.

6- Morkoç, H.; Özgür, Ü. Zinc Oxide: Fundamentals, Materials and Device Technology, 1st ed.;

WILEY-VCH: Weinheim, Germany, (2009); ISBN 978-3-527-40813-9.

7- Mustaqima, M.; Liu, C. ZnO-based nanostructures for diluted magnetic semiconductor. Turk.

J. Phys. (2014),38, 429-441.

8- Djerdj, I.; Jaglici'c, Z.; Arcon, D.; Niederberger, M. Co-Doped ZnO nanoparticles: Minireview. Nanoscale (2010),2, 1096-1104.

9- Yang, Z. A perspective of recent progress in $\mathrm{ZnO}$ diluted magnetic semiconductors. Appl. Phys. A 2013, 112, 241-254.

10- Liu, C.; Yun, F.; Morkoç, H. Ferromagnetism of ZnO and GaN: A Review. J. Mater. Sci. Mater. Electron. 2005,16, 555-597.

11- P. Bindu and Sabu Thomas, J .Theor.Appl.Phys. 8,123 (2014).

12- Niasari, M.S., Davar, F., Mazaheri, M.: Preparation of $\mathrm{ZnO}$ nanoparticles from [bis (acetylacetonato) zinc (II)]-oleylamine complex by thermal decomposition. Maters.Lett.62, 1890-1892 (2008).

13- Ungar, T.: Characterization of nanocrystalline materials by x-ray line profile analysis. J. Mater. Sci. 42, 1584-1593 (2007).

14- J. Hwang, T. Timusk, and G. D. Gu, Nature 427, 714 (2004).

15- M. Norman, Nature 427, 692 (2004).

16- Harish Kumar and Renu Rani, International Letters of Chemistry, Physics and Astronomy 14, 26 (2013).

17- Wan Rafizah Wan Abdullah, AzmiZakaria and MohdSabriMohdGhazali, Int. J. Mol. Sci. 13, 5278 (2012).

18- A.A. Othman, M.A.Othman, E.M.M. Ibrahim and ManarA.Ali, Ceramic International 43, 527 (2017).

19-A.Sedky , AtifMossad Ali and Mansour Mohamed, Optical and Quantum Electronics 52,42, 1(2020).

20- J. Jadhav, M. Patange, S. Biswas, Carbon Sci. Tech. 5 (2) (2013) 269

21- S.A. Amin and A.Sedky, Mater. Res. Express 6, 065903 (2019).

22- Arda L, Ozturk O, Asikuzun E and Ataoglu S P 2013 Tech. 235 479-84

23- Ram M, Bala K, Sharma H and Negi N S 2016 AIP Conf. 1731050104

24- Cherifi Y, Chaouchi A, Lorgoilloux Y, Rguiti M, Kadri A and Courtois C 2016 PAC. 10 125-35

25- Ghosh C K, Malkhandi S, Mitra M K and Chattopadhyay K K 2008 J. Phys. D: App. Phys. 41245113

26- M. Andres Verges and A. R. West, J. Electroceramics 1:2, 125 (1997).

27- Shukla R K, Srivastava A, Dubey K C and Kumar N 2009 Int. Conf. on Emerging Trends in Electronic and Photonic Devices \& Systems (ELECTRO'09) pp 465-6

28- J. Jose and Abdul Khadar, Nanostruct. Mater.11, 8, 1091 (1999).

29- J. Jose and Abdul Khadar, Mater. Sci. Eng.A (304-306), 810 (2001). 
30- R. Tripathi, A. Kumar, C. Bharti, T.P. Sinha, Dielectric relaxation of ZnO nanostructures synthesized by soft chemical method, Curr. Appl. Phys., 10 (2010)

676-681.

31- D. Fernandez-Hevia, M. Peiteado, J. de Frutos, A.C. Caballero, J.F. Fernandez, Wide range dielectric spectroscopy of $\mathrm{ZnO}$ based varistorsas a function of sintering time, J. Eur. Ceram. Soc., 24 (2004) 1205-1208.

32- T.A. Baeraky, "Microwave measurements of dielectric properties of zinc oxide at high temperature", Egypt. J. Solids, 30 (2007) 13-18; M. Ram, "A.c. conductivity and relaxation in LiCoVO4 ceramics", Curr. Appl. Phys., 10 (2010) 1013-1016.

33- H. Saadi, F.I.H. Rhouma, Z. Benzarti, Z. Bougrioua, S. Guermazi, K. Khirouni, Electrical conductivity improvement of Fe doped ZnOnanopowders, Mater. Res. Bull. 129 (2020) 110884.

34- P. Sahay, S. Tewari, R. Nath, S. Jha, M. Shamsuddin, "Studies on ac response of zinc oxide pellets", J. Mater. Sci., 43 ,13 (2008) 4534-4540.

35- J. Jose, M. Abdul Khadar, "Role of grain boundaries on the electrical conductivity of nanophase zinc oxide", Mater. Sci. Eng. A, 304 (2001) 810-813.

36- C. Panatarani, I.W. Lenggoro, K. Okuyama, "The crystallinity and the photoluminescent properties of spray pyrolyzedZnO phosphor containing Eu2+ and Eu3+ ions", J. Phys. Chem. Solids, 65 (2004) 1843-1847.

37- Y.S. Wang, P.J. Thomas, P. O’Brien, "NanocrystallineZnO with ultraviolet luminescence", J. Phys. Chem. B, 110 (2006) 4099-4104.

38- A. Sajid Ali, N. Ambreen, F. Bushara, W. Khan, A.H. Naqvi, "Investigation on structural, optical and dielectric properties of Co doped $\mathrm{ZnO}$ nanoparticles synthesized by gel-combustion route", Mater. Sci. Eng. B, 177 (2012) 428-435.

39- S. Singh, P. Dey, J.N. Roy, S.K. Mandal, Tunable dielectric constant with transition metal doping in Zn1-x(MnTM)xO (TM 1/4 Co, Fe) nanocrystals, J. Alloys Compd. 642 (2015) 15-21.

40- R. Zamiri, A. Kaushal, A. Rebelo, J.M.F. Ferreira, Er doped ZnOnanoplates: synthesis, optical and dielectric properties, Ceram. Int. 40 (2013) 1635-1639.

41- K. Irshad, M.T. Khan, A. Murtaza, Synthesis and characterization of transition- metalsdoped $\mathrm{ZnO}$ nanoparticles by sol-gel auto-combustion method, Phys. B Condens. Matter 543 (2018) 1-6.

42- K. Omri, A. Bettaibi, K. Khirouni, L. El Mir, The optoelectronic properties and role of $\mathrm{Cu}$ concentration on the structural and electrical properties of $\mathrm{Cu}$ doped $\mathrm{ZnO}$ nanoparticles, Phys. B Condens. Matter 537 (2018) 167-175.

43- R. Joshi, P. Kumar, A. Gaur, K. Asokan, Structural, optical and ferroelectric properties of V doped ZnO, Appl. Nanosci. 4 (2014) 531-536.

44- J. Singh, R.C. Singh, Structural, optical, dielectric and transport properties of ball mill synthesized ZnO-V2O5 nano-composites, J. Mol. Struct. 1215 (2020) 128261.

45- S. Das, S. Das, S. Sutradhar, Enhanced dielectric behavior and ac electrical response in GdMn-ZnO nanoparticles, Alloys Comp. 726 (2017) 11-21.

46- H. Saadi, F.I.H. Rhouma, Z. Benzarti, Z. Bougrioua, S. Guermazi, K. Khirouni, Electrical conductivity improvement of Fe doped ZnOnanopowders, Mater. Res. Bull. 129 (2020) 110884.

47- ChediaBelkhaoui, ,NissafMzabi, HichemSmaoui, Enhancing the structural, optical and electrical properties of ZnOnanopowders through $(\mathrm{Al}+\mathrm{Mn})$ doping, Results in Physics 12 (2019) 1686-1696

48- A. Sajid Ali, N. Ambreen, F. Bushara, W. Khan, A.H. Naqvi, "Investigation on structural, optical and dielectric properties of $\mathrm{Co}$ doped $\mathrm{ZnO}$ nanoparticles synthesized by gel-combustion route", Mater. Sci. 133Y.Cherifi et al. / Processing and Application of Ceramics 10 [3] (2016) 125-135 Eng. B, 177 (2012) 428-435.

49- I. Khan, S. Khan, R. Nongjai, H. Ahmed, W. Khan, "Structural and optical properties of gelcombustion synthesized Zr doped ZnO nanoparticles", Opt. Mater., 35 (2013) 1189-1193. 
50- F. Ahmed, S. Kumar, N. Arshi, M.S. Anwar, S.N. Heo, B.H. Koo, "Doping effects of Co2+ ions on structural and magnetic properties of ZnOnanoparticles", Acta Mater., 60 (2012) 51905196.

51- W. Huang, X. Tanga, I. Felnerb, Y. Koltypin, A. Gedanken, "Preparation and characterization of FexOy -TiO2 via sonochemical synthesis", Mater. Res. Bul., 37 (2002) 1721-1735.

52- P. Sahay, S. Tewari, R. Nath, S. Jha, M. Shamsuddin, "Studies on ac response of zinc oxide pellets", J. Mater. Sci., 43 [13] (2008) 4534-4540.

53- J. Jose, M. Abdul Khadar, "Role of grain boundaries on the electrical conductivity of nanophase zinc oxide", Mater. Sci. Eng. A, 304 (2001) 810-813.

54- Sedky A and El-Suheel E (2010) Physics Research International 2010: 1.

55- Sedky A, AymanSawalha and AmalYaseen (2009) Physica B 404: 3519.

56- S. Zhao, P. Li, Y. Wei, Powder Tech. 224 (2012) 390.

57- V.T. Bhugul, G.N. Choudhari, International Journal of Scientific and Research Publications, $5,1,1(2015)$.

58- D. Hou, R. Zhao, Y. Wei, C. Zhen, C. Pan, G. Tang, Curr. App. Phys. 10 (2010) 124.

59- A. Morais , R. A. Torquato , U. C. Silva , C. Salvador, C. Chesman, Cerâmica 64, 627-631

(2018) 627-631

60-Anindita Samanta, M.N. Goswami, P.K. Mahapatra, J of Alloys and Compounds 730 (2018) 399

61- Guangqing Pei, Changtai Xia, Shixun Cao, Jungang Zhang, Feng Wu and Jun Xu, JMMM 302, 2, 340 (2006).

62- CHOW L., LUPAN O., CHAI G. KHALLAF H., ONO L.K., ROLDAN CUENY B., TIGINYANU I.M., URSAKI V.V., SONTEA V., SCHULTE A., Sensor Actuat. A-Phys., 189 (2013), 399.

63- K.S. Shankar, S. Kar, G. N. Subbanna and A .K .Raychaudhuri, Sol. State. Comm. 129, 479 (2004).

64- A. Dutta, N. Gayathri and R. Ranganathan, Phys. Rev. B 68, 054432 (2003).

65-Özgür Ü ,Ya A, Alivov I, Liu C, Teke A, ReshchikovM A, Doğan S, AvrutinC V, Cho S J, Morkoçd, J. Appl. Phys. 98, 041301 (2005).

66- A. Sedky and S. B. Mohamed, Materials Science-Poland, 32(1), 16 (2014).

67- S. Aksoy, Y. Caglar, S. Ilican, M. Caglar, Chem. Eng. Civ. Eng. Mech. Eng. 227, (2010).

68- U. Seetawan, S. Jugsujinda, T. Seetawan, A. Ratchasin, C. Euvananont, C. Junin, C. Thanachayanont, P. Chainaronk, Mater. Sci. Appl. 2 , 1302 (2011).

69-Wojnarowicz, J.; Chudoba, T.; Gierlotka, S.; Sobczak, K.; Lojkowski, W. Crystals 2018, 8, 179.

70- M.A.Aksan, M.E, Yakinci, J Alloy Compd.433, 22 (2007).

71- X.S. Wang, Z.C. Wu, J.F. Webb, Z.G. Liu, Appl. Phys. A 77, 561 (2003).

72- Xuhai Li, Xiuxia Cao, Liang Xu, Lixin Liu, Yuan Wang, ChuanminMeng and ZhigangWang, J. Alloys \& Compounds 675, 90 (2016).

73- C. M. Jay, M. Sathya, K. Pushpanathan, Acta Metall. Sin.(Engl. Lett.), 28, 394 (2015).

74- H. S. Wasly, Journal Of Al Azhar University Ngineering Sector13, 49, 1312( 2018).

75- Wali Muhammad, NaimatUllah, Muhammad Haroona and Bilal Haider Abbas, RSC Adv., 2019, 9, 29541.

76- G. I. Dovbeshko, N. Y. Gridina, E. B. Kruglova and O. P. Pashchuk, Talanta, 2000, 53, 233246.

77-T. Srinivasulu, K. Saritha, K.T. Ramakrishna Reddy, Modern Electronic Materials

3,2, 2017, (76-85). 
78- K. Raja, P.S. Ramesh, D. Geetha, Structural, FTIR and photoluminescence studies of Fe doped ZnOnanopowder by co-precipitation method, Spectrochem. ActaA- Mol. Biomol. Spectrosc. 131 (2014) 183-188.

79- M. Huleihel, A. Salman, V. Erukhimovitch, J. Ramesh, Z. Hammody and S. Mordechai, J. Biochem. Biophys. Methods, 2002, 50, 111-121.

80- H. Fabian, M. Jackson, L. Murphy, P. H. Watson, I. Fichtner and H. H. Mantsch, Biospectroscopy, 1995, 1, 37-45.

81- B. R. Wood, M. A. Quinn, B. Tait, M. Ashdown, T. Hislop, M. Romeo and D. McNaughton, Biospectroscopy, 1998, 4, 75-91.

82- Muneer M. Ba-Abbad, Abdul Amir H. Kadhum, Abu BakarMohamad, Mohd S. TakriffandKamaruzzamanSopian, The effect of process parameters on the size of $\mathrm{ZnO}$ nanoparticles synthesized via the sol-gel technique, J. Alloy. Compd. 550 (2013) 63-70.

83- V.T. Bhugul, G.N. Choudhari, Synthesis and Studies on Nanocomposites of polypyrrole- Aldoped zinc oxide Nanoparticles, International Journal of Scientific and Research Publications5, 1, ISSN 2250-3153 (2015).

; J. Santhoshkumar, S. V. Kumar and S. Rajeshkumar, Resour.-Effic. Technol., 2017, 3, 459465.

84- AnandhaveluSanmugam, DhanasekaranVikraman, SethuramanVenkatesan and HuiJoon Park, Journal of Nanomaterials 2017, Article ID 7536364, (1-8).

85- M. Haase, H. Weller, and A. Henglein, Journal of Physical Chemistry, 92, 2, 482 (1988).

86- P. Mitra, S. Mondal, Structural and morphological characterization of $\mathrm{ZnO}$ thin films synthesized by successive ion layer adsorption and reaction, Prog. Theor. Appl. Phys. 1 (2013) $17-31$.

87- R.D. Waldron, phys. Rev. 99(1955).

88- S.A. Mazen, H.M. Zaki, S.F. Mansour, Int. J. Pure Appl. Phys. 3, 40 (2007).

89-D. El-Said Bakeer, Applied Physics A (2020) 126:443; https://doi.org/10.1007/s00339-02003625-Z

90- R.D. Waldron, Phys. Rev. 99, 1727 (1995).

91- A.V. Anupama, V. Rathod, V.M. Jali, B. Sahoo, J. Alloys Compd. 728, 1091 (2017).

92- K.B. Modi, P.Y. Raval, S.J. Shah, Inorg. Chem. 54, 1543 (2015).

93- I.N. Frantsevich, F.F. Voronov, S.A. Bakuta, Handbook on Elastic Constants and Moduli of Elasticity for Metals and Nonmetals (NaukovaDumka, Kiev, 1982).

94- A Sedky, SA Amin, M Mohamed, Applied Physics A 125, 308 (2019).

95- MariemChaari, Adel matoussi, ZouheirFakhfakh, materials sciences and applications 2, 765 (2011).

96-T.P. Rao, M.C.S. Kumar, A.Safarullaa, V. Ganesan, S. R. Barman, C. Sanjeeviraja, Physica B 405,9, 2226 (2010).

97- H.C. Ong, A.X.E. Zhu, G.T. Du, Appl. Phys. Lett. 80, 941 (2002).

98- C. Wang, P. Zhang, J. Yue, Y. Zhang, L. Zheng, Physica B 403, 2235 (2008).

99- D.I. Rusu, G.G. Rusu and D. Luca, ActaPhysicaPolonica A 119, 6, 850 (2011).

100- MUKHTAR M., MUNISA L., SALEH R., Mater. Sci. Appl., 3 (2012), 543.

101- SRINIVASAN N., KANNAN J.C., Mater. Sci.-Poland, 33 (2015), 205.

102- K.B. Modi, J.D. Gajera, M.P. Pandya, H.G. Vora, H.H. Joshi, Pramana 62, 1173 (2004).

103- S.M. Patange, S.E. Shirsath, S.P. Jadhav, J. Mol. Struct. 1038, 40 (2013).

104- D. Ravinder, T. Alivelumanga, Mater. Lett.37, 51 (1998).

105- B. Rajesh Babu, T. Tatarchuk, Mater.Chem.Phys.207, 534 (2018).

106- A. Sedky, Atif Ali, HH Somailyand HAlgarni, Accepted for publication in Optical and Quantum Electronics (2021).

107- A.A. Othman, M.A.Othman, E.M.M. Ibrahim and Manar.A.Ali, Ceramic International 43, 527 (2017). 
108- H. M. Ali, H. A. Mohamed, and S. H. Mohamed, Eur. Phys. J. Appl. Phys. 31, 87 (2005). 109- S. Abdalla, K. Easawi, T.A. El-Brolossy, G.M. Yossef, S. Negm and H. Talaat, Rev. Sci. Instrum. 74, 1, 848 (2003).

110- A.A. Othman, M.A.Othman, E.M.M. Ibrahim and Manar.A.Ali, Ceramic International 43, 527 (2017).

111- H. M. Ali, H. A. Mohamed, and S. H. Mohamed, Eur. Phys. J. Appl. Phys. 31, 87 (2005).

112-Raid A. Ismail ,Abdulrahman K. Ali , Mukhlis M. Ismail and Khaleel I. Hassoon, ApplNanosci (2011) 1:45-49.

113- Abdel-Khalek, H., Shalaan, E., El Salam, M.A., El-Sagheer, A.M., El-Mahalawy, A.M.:

Effect of thermal annealing on structural, linear and nonlinear optical properties of 1, 4, 5, 8naphthalene tetracarboxylic dianhydride thin films. J. Mol. Struct. 1178, 408-419 (2019).

114-Wang, Y.G., Lau, S.P., Lee, H.W., Yu, S.F., Tay, B.K., Zhang, X.H., Hng, H.H.:

Photoluminescence study of $\mathrm{ZnO}$ films prepared by thermal oxidation of $\mathrm{Zn}$ metallic films in air. J. Appl. Phys. 94, 354-358 (2003b).

115- Sedky, A., Amin, S.A., Mohamed, M.: Electrical, photoluminescence and ferromagnetic characterization of pure and doped $\mathrm{ZnO}$ nanostructures. Appl. Phys. A. 125, 308 (2019). 116- Ismail, R.A., Ali, A.K., Ismail, M.M., Hassoon, K.I.: Preparation and characterization of colloidal $\mathrm{ZnO}$ nanoparticlesusing nanosecond laser ablation in water. Appl. Nanosci. 1, 45-49 (2011).

117- S.J. Darzi and A.R. Mahjoub and A. Nilehi, Phys. E Low-Dimens.Syst.Nanostructures 42, 1, 76 (2009).

118- A. El-Denglawey, Journal of Luminescence 194, 381 (2018).

119- J. Yu, X. Zhao and Q. Zhao, Mater. Chem. Phys. 69,25 (2001).

120- Suresh Sagadevan, Kaushik Pal, ZairaZamanChowdhury and M. EnamulHoque, Journal of Sol-Gel Science and Technology volume 83, pages394-404(2017).

121- H. Abdel-Khalek, E. Shalaan, Mohamed Abd- El Salam, Aida M. El-Sagheer and Ahmed M. El-Mahalawy, Journal of Molecular Structure 1178, 408 (2019).

122- H.M. Zeyada, M.M. EL-Nahass, I.S. El-Ashmawi and A.A. Habashi, Current Applied Physics 13, 9, 1960 (2013).

123- Hazem Mahmoud Ali and Ahmed Mohamed Abdel Hakeem, Eur. Phys. J. Appl. Phys.72,10301(2015).

124-A. El-Denglawey, Non-Cryst.Solids 357,1757 (2011).

125- G. B. Parravicini, E. R. Mognaschi, D. Comoretto, G. Dellepiane, and A. Brillante, Synthetic Metals 101,1-3, 467(1999).

126- S. Selvakumar, R. Murugaraj, E. Viswanathan, S. Sankar, and K. Sivaji, Journal of Molecular Structure, 1056-1057, 152(2014).

127- A. A. Attia, H. S. Soliman, M. M. Saadeldin, and K. Sawaby, Synthetic Metals 205, 139 (2015).

128- Mehedi Hassan M, Khan W, Azam A, Naqvi AH. Influence of Cr incorporation on structural, dielectric and optical properties of $\mathrm{ZnO}$ nanoparticles. J Ind Eng Chem 2015;21:283-91.

129- Zamiri R, Kaushal A, Rebelo A, Ferreira JMF. Er doped ZnO nanoplates: synthesis, optical and dielectric properties. Ceram Int 2014;40:1635-9.

130- Zamiri R, Singh B, Bdikin I, Rebelo A, Belsley MS, Ferreira JMF. Influence of Mg doping on dielectric and optical properties of $\mathrm{ZnO}$ nano-plates prepared by wet chemical method. Solid State Commun 2014;195:74-9.

131- J. Singh, R.C. Singh, Structural, optical, dielectric and transport properties of ball mill synthesized ZnO-V2O5 nano-composites, J. Mol. Struct. 1215 (2020) 128261.

132- H. Saadi, F.I.H. Rhouma, Z. Benzarti, Z. Bougrioua, S. Guermazi, K. Khirouni, Electrical conductivity improvement of Fe doped ZnO nanopowders, Mater. Res. Bull. 129 (2020) 110884. 
133- A. Samanta, M.N. Goswami, P.K. Mahapatra, Fe-doped ZnO nanoparticles as novel photonic and multiferroic semiconductor, Mater. Chem. Phys. 240 (2020) 122180.

134- M.M. Hassan, A.S. Ahmed, M. Chaman, W. Khan, A.H. Naqvi, A. Azam, Structural and frequency dependent dielectric properties of Fe3p doped ZnO, Mater. Res. Bull. 47 (2012) 3952-3958.

135- J. Singh, Virpal, S. Sharma, R.C. Singh, Effect of Fe2O3 doping on structural properties of ZnO-V2O5 based varistor system, AIP Conference Proc. 1832 (2017) 120021.

136- H. M. Zeyada, F. M. El-Taweel, M. M. El-Nahass, and M. M. ElShabaan, Chinese Physics B 25, 7, ID 077701, (2016).

137- M. Pollak and T. H. Geballe, Physical Review122, 6, 1742(1961).

138-A. R. Long, Advances in Physics 31, 5, 553 (1982).

139- M. Pollak and T. H. Geballe, Physical Review122, 6, 1742(1961).

140- A.K. Jonscher, "The 'universal' dielectric response", Nature, 267 (1977) 673.

141- R. F. Loane, P. Xu, and J. Silcox, ActaCrystallographica Section A Foundations of Crystallography, 47, 3, 267(1991).

142- S. R. Elliott, "A.c. conduction in amorphous chalcogenide and pnictide semiconductors," Advances in Physics, 36, 2, 135(1987).

143-Yacine Cherifi, Ahcène Chaouchi1, YannickLorgoilloux, Mohammed Rguiti, Processing and Application of Ceramics 10 [3] (2016) 125-135

144- N.Ch. Ramesh Babu, M.A. Valente, N. NarasimhaRao, M.P.F. Graça, G. Naga Raju, M.

Piasecki, I.V. Kityk, N. Veeraiah, "Low temperature dielectric dispersion and electrical

conductivity studies on $\mathrm{Fe} 2 \mathrm{O} 3$ mixed lithium yttrium silicate glasses", J.

Non-Crystalline Solids, 358 (2012) 3175-3186.

145- J. C. Giuntini, J. V. Zanchetta, D. Jullien, R. Eholie, and P. Houenou, Journal of Noncrystalline Solids, 45, 1, 57(1981).

146- Z. M. E. Fahim, S. M. Bouzzine, Y. AitAicha, M. Bouachrine, and M. Hamidi, Research on Chemical Intermediates, 44, 3, 2009 (2018).

147- A. Oueslati, F. Hlel, K. Guidara, and M. Gargouri, Journal of Alloys and Compounds, 492, $1-2,508$ (2010).

148- J. Singh, R.C. Singh, J. Mol. Struct. 1215, 128261 (2020).

149- T. Elkar, N. Mzabi, M. Ben hassine, P. Gemeiner, B. Dkhil, S. Guermazi, H. Guermazi, Structural and optical investigation of $(\mathrm{V}, \mathrm{Al})$ doped and co-doped ZnOnanopowders: tailored visible luminescence for white light emitting diodes, Superlattice. Microst. 122 (2018) 349-361.

150- M. Andres Verges and A. R. West, J. Electroceramics 1:2, 125 (1997).

151- J. Jose and Abdul Khadar, Mater. Sci. Eng.A (304-306), 810 (2001).

152- J. Jose and Abdul Khadar, Nanostruct. Mater.11, 8, 1091 (1999).

153- J. Jose and Abdul Khadar, Acta Mater. 49, 729 (2001).

154- W. C. Nan, A. Tschope, S. Holten, H. Kliem and R. Birringer, J. Appl. Phys. 85, 11, 7735 (1999).

155- Z. Brankoviz, G. Brankoviz, D. Poleti and A. J. Varela, Ceram. Int. 27, 1, 115 (2001).

156 -Glot, E. Bartolomeo and E. Traversa, Eur. Ceram.Soc.19, 715 (1999).

157- Zhen Zhou, K. Kato, T. Komaki, M. Yoshino, H. Yukawa, M. Morinaga and K. Morita, J.

Eur. Ceram. Soc. 24, 139 (2004).

158- J. Han, P. Q. Mantas and A. M. R. Senos, J. Eur. Ceram. Soc. 20, 2753 (2000). 14- J. Han,

A. M. R. Senos and P. Q. Mantas, Mater. Chem. Phys. 75,117 (2002).

159 -LianGao, Qiang Li and Weiling Luan, J. Am. Ceram.Soc.85, 4, 1016 (2002).

160- A. Sedky, M. I. Youssif and T. A. El-Brolossy, Nature and Science 14(2) 66-73 (2016). 